\title{
Old-timers and newcomers: The shrews and heterosoricids from the Ribesalbes-Alcora Basin (East of Spain)
}

\author{
Vicente D. Crespo, Ana Fagoaga, Plini Montoya, and Francisco J. Ruiz-Sánchez
}

\begin{abstract}
The zone of Araia d'Alcora in the Ribesalbes-Alcora Basin (Spain, early Miocene, biozone $C, M N 4$ ) yielded a relatively rich assemblage of shrews for an lberian site, composed by Oligosorex thauensis, cf. Soricella discrepans, Paenelimnoecus micromorphus and Heterosorex neumayrianus. The fossils of $O$. thauensis, the most abundant taxon, significantly increase our knowledge regarding the morphology of the species. It signals the last known occurrence of this shrew and extending its record to a MN4 site. This species is competing with other shrews in the studied sites. Paenelimnoecus micromorphus is recorded for the first time in the Iberian Peninsula. Soricella discrepans is a typical species from Central Europe; if its occurrence is confirmed in Ribesalbes-Alcora, it would represent the only record of this species in MN4 from the Iberian Peninsula. The material of Heterosorex neumayrianus, a species relatively common in the Iberian Peninsula but always poorly represented, constitutes the best Spanish collection described. When dimylids are present Heterosorex is uncommon.
\end{abstract}

Vicente D. Crespo. Consejo Nacional de Investigaciones Científicas y Técnicas, División de Paleontología de Vertebrados, Museo de La Plata (UNLP), Paseo del Bosque s/n, B1900FWA La Plata, Argentina. vidacres@gmail.com Museo Paleontológico de Alpuente, Av. San Blas 17, Alpuente, 46178 Valencia, Spain.

Museu Valencia d'Història Natural, L'Hort de Feliu, P.O. Box 8460, Alginet, 46018 Valencia, Spain. Ana Fagoaga. Museu Valencia d'Història Natural, L'Hort de Feliu, P.O. Box 8460, Alginet, 46018 Valencia, Spain.

Departament de Geologia, Universitat de València, Dr. Moliner 50, 46100, Burjassot, Valencia, Spain. ana.fagoaga@uv.es

Plini Montoya. Departament de Geologia, Universitat de València, Dr. Moliner 50, 46100, Burjassot, Valencia, Spain. plinio.montoya@uv.es

Francisco J. Ruiz-Sánchez Museu Valencia d'Història Natural, L'Hort de Feliu, P.O. Box 8460, Alginet, 46018 Valencia, Spain.

Crespo, Vicente D., Fagoaga, Ana, Montoya, Plini, and Ruiz-Sánchez, Francisco J. 2019. Old-timers and newcomers: The shrews and heterosoricids from the Ribesalbes-Alcora Basin (East of Spain). Palaeontologia Electronica 22.3.64 1-22. https://doi.org/ $10.26879 / 999$

palaeo-electronica.org/content/2019/2777-soricids-from-ra-basin

Copyright: October 2019 Paleontological Society.

This is an open access article distributed under the terms of Attribution-NonCommercial-ShareAlike 4.0 International (CC BY-NC-SA 4.0 ), which permits users to copy and redistribute the material in any medium or format, provided it is not used for commercial purposes and the original author and source are credited, with indications if any changes are made.

creativecommons.org/licenses/by-nc-sa/4.0/ 
Departament de Geologia, Universitat de València, Dr. Moliner 50, 46100, Burjassot, Valencia, Spain. francisco.ruiz@uv.es

Universidad Estatal Península de Santa Elena, 7047, Santa Elena, Ecuador.

Keywords: Soricidae; Heterosoricidae; early Miocene; systematics; Iberian Peninsula; paleoecology

Submission: 12 May 2019. Acceptance: 1 October 2019.

\section{INTRODUCTION}

The systematic palaeontology of the soricids sensu lato, and in general all the Eulipotyphla, is poorly studied in the early Miocene in the Iberian Peninsula. Although frequently found in European karstic filling sites, but more scarce in lacustrine sites (Klietmann et al., 2014), they are mostly represented by scarce material, consisting of isolated molars, and they are mainly known through faunal lists or preliminary reports in Spain (Van den Hoek Ostende and Furió, 2005; Van der Meulen et al., 2011; Van den Hoek Ostende et al., 2016; Furió et al., 2018), or they are merely included in ecological analyses (Van den Hoek Ostende, 2001a). Therefore, a complete descriptive study of this group is very important to understand their evolution throughout the early Miocene. Specially, at the initial steps of the Miocene Climatic Optimum located in the uppermost early Miocene, closed to the radical change of the rodent faunas at the end of the cricetid vacuum.

During the early Miocene, the family Soricidae was far from being a dominant group in the Iberian Peninsula as it is nowadays in current eulipotyphlan faunas (Van den Hoek Ostende et al., 2016; Furió et al., 2018). Its Spanish fossil record in this time interval is relatively reduced (Van den Hoek Ostende and Furió, 2005; Table 1).

On the other hand, the family Heterosoricidae, in the early Miocene of Iberian Peninsula is monospecific in MN4 zone. For that reason, it is considered as a transient genus (Van den Hoek Ostende et al., 2016). The record of this family is limited in the Spanish sites (Table 1). Near the sites studied in the locality of Buñol, Robles et al. (1991) described the two species (Table 1), but this material needs a revision in the light of more recent discoveries (Van den Hoek Ostende and Furió, 2005).

\section{GEOGRAPHIC AND GEOLOGIC SETTING}

The studied stratigraphic column is located in the Ribesalbes-Alcora Basin (eastern Iberian Peninsula; Figure 1; Agustí et al., 1988; Crespo et al., 2019a) near the village of Araia d'Alcora. This syn- tethic stratigraphic column is composed of seven sections (Mas dels Coixos, Mas de Torner, Araia Cantera Sud, Barranc de Campisano, Foieta la Sarra, Mas d'Antolino B and Corral de Brisca) of grey and yellow mudstones, limestones and sandstones, about $100 \mathrm{~m}$ thick (Crespo et al., 2019a), which belongs to the "Unit Three" sensu Anadón (1983).

Agustí et al. (1988) reported the first sites with mammalian remains from the Ribesalbes-Alcora Basin. Until now, up to 45 sites have been described from the seven sections by Crespo et al. (2019a). The record includes the southernmost record of the herpetotheriid Amphiperaterium frequens (von Meyer 1846) has been documented (Furió et al. 2012), the new species Plesiodimylus ilercavonicus Crespo, Furió, Ruiz-Sánchez and Montoya, 2018 (Crespo et al., 2018), and the abundant remains of talpids (Crespo et al., 2019b).

The studied sections represent a stratigraphic range corresponding to local biozone $C$ from the Calatayud-Daroca Basin (MN4, lower Aragonian, early Miocene), in the chronologic interval 16.5-16 Ma according to van der Meulen et al. (2012) (Crespo et al., 2019a).

\section{MATERIAL, METHODS AND ABBREVIATIONS}

The photographic images of the specimens were taken with a Scanning Electron Microscope HITACHI 4800 at the Servei Central de Suport a la Investigació Experimental (SCSIE) of the University of València Estudi General (UVEG). The fossil material is stored at the Museu de la Universitat de Valencia d'Historia Natural (MUVHN), Burjassot, Spain.

For the soricids and the heterosoricids, we have used the nomenclature and the measuring methods of Reumer (1984). Measurements are given in millimetres and were taken using a Leica MZ75 binocular microscope, by means of displacement of a mechanical stage, connected to a Sony Magnescale measuring equipment. Lower teeth are designated with lower-case letters (lower antemolars: a1, a2 and a3; lower premolar: p4; lower molars: $\mathrm{m} 1, \mathrm{~m} 2$ and $\mathrm{m} 3$; lower incisive: i) and 
TABLE 1. Early Miocene sites from Spain with remains of shrews and heterosoricids, excluding this work (Agustí et al., 1988; Van der Meulen, 2003; Van den Hoek Ostende and Furió, 2005; Van den Hoek Ostende et al., 2009; 2017; Van der Meulen et al., 2012; Furió et al., 2018; Jovells-Vaquè et al., 2018).

\begin{tabular}{|c|c|c|}
\hline Taxon & Basin & Site/s \\
\hline \multirow[t]{6}{*}{ Soricidae indet. } & Almazán & Cetina de Aragón \\
\hline & Calatayud-Montalbán & $\begin{array}{l}\text { Ateca 1, 3; Bañon 5; Moratilla 1; Olmo Redondo 3; } \\
\text { Valtorres }\end{array}$ \\
\hline & Ebro & La Nasa 1, 6; Mediavilla; Rincón del Bu \\
\hline & Madrid & O’Donnell \\
\hline & Rubielos de Mora & Rubielos de Mora 1, 2 \\
\hline & Teruel & Montalvos 2 \\
\hline \multirow[t]{3}{*}{$\begin{array}{l}\text { Oligosorex (cf. or aff.) thauensis (Crochet, } \\
\text { 1975) }\end{array}$} & Calatayud-Montalbán & $\begin{array}{l}\text { Agreda; Bañon 2; Moratilla 1; Ramblar 1, 3, 4, 7; } \\
\text { San Roque 4a }\end{array}$ \\
\hline & Ebro & $\begin{array}{l}\text { Barranco del Fraile; Cabezo Vaquero; Fuenmayor } \\
\text { 2; Valhondo } 1\end{array}$ \\
\hline & Rubielos de Mora & Alto de Ballester 1 \\
\hline \multirow[t]{2}{*}{ Oligosorex sp. } & Calatayud-Montalbán & $\begin{array}{l}\text { Artesilla, Olmo Redondo } 1,2 \text { and } 3 \text {, San Marcos, } \\
\text { San Roque } 2 \text { and } 3 \text {, Villafeliche } 2 a \text {, Vargas } 1 A, 2 A \text {, } \\
4 A, 4 B \text { and } 4 B B\end{array}$ \\
\hline & Magro & Buñol \\
\hline \multirow{2}{*}{$\begin{array}{l}\text { Clapasorex (cf.) alvarezae van den Hoek } \\
\text { Ostende, } 2003\end{array}$} & Calatayud-Montalbán & Navarrete del Río, Ramblar 1 and 3, Valhondo 1 \\
\hline & Rubielos de Mora & Alto de Ballester 1 \\
\hline Soricella discrepans Doben-Florin, 1964 & Calatayud-Montalbán & Navarrete del Río, Ramblar 1 \\
\hline Miosorex grivensis (Deperet, 1892) & Calatayud-Montalbán & $\begin{array}{l}\text { Munebrega 1, San Marcos, Torralba 1, Vargas } 4 \mathrm{~A} \\
\text { and } 4 \mathrm{~B}\end{array}$ \\
\hline "Florinia" & Calatayud-Montalbán & $\begin{array}{l}\text { Olmo Redondo 2, San Roque 1, 2, 3, 4a and 5, } \\
\text { Vargas 1A, 2A, 4A, 4B and 4BB }\end{array}$ \\
\hline \multirow[t]{2}{*}{ Paenelimnoecus (cf.) truyolsi (Gibert, 1975) } & Calatayud-Montalbán & San Marcos, Vargas $1 \mathrm{~A}$ \\
\hline & Rubielos de Mora & Alto de Ballester 1 \\
\hline \multirow[t]{4}{*}{ Heterosorex sp. } & Almazán & Cetina de Aragón \\
\hline & Calatayud-Montalbán & $\begin{array}{l}\text { Artesilla, Navarrete del Río, Ramblar 1, Vargas } 1 \mathrm{~A} \text {, } \\
3,4 \mathrm{~A} \text { and } 4 \mathrm{BB}\end{array}$ \\
\hline & Ebro & Alto de Ballester 1 \\
\hline & Madrid & O’Donnell \\
\hline \multirow{4}{*}{$\begin{array}{l}\text { Heterosorex (cf.) neumayrianus (Schlosser, } \\
\text { 1887) }\end{array}$} & Magro & Buñol \\
\hline & Ribesalbes-Alcora & Mas de Antolino 2 \\
\hline & Teruel & Montalvos 2 \\
\hline & Vallès-Penedès & Les Cases de la Valenciana \\
\hline Heterosorex ruemkeae Doukas, 1986 & Magro & Buñol \\
\hline
\end{tabular}

upper teeth are written in upper case letters (upper antemolars: A1, A2, A3 and A4; upper molars: M1, M2 and M3; upper premolar: P4; upper incisive: I).

Throughout the text, the names of the sections often appear abbreviated as follows: MCX:
Mas dels Coixos; MTR: Mas de Torner; BC: Barranc de Campisano; FS: Foieta la Sarra; MAB: Mas d'Antolino B; CBR: Corral de Brisca. 

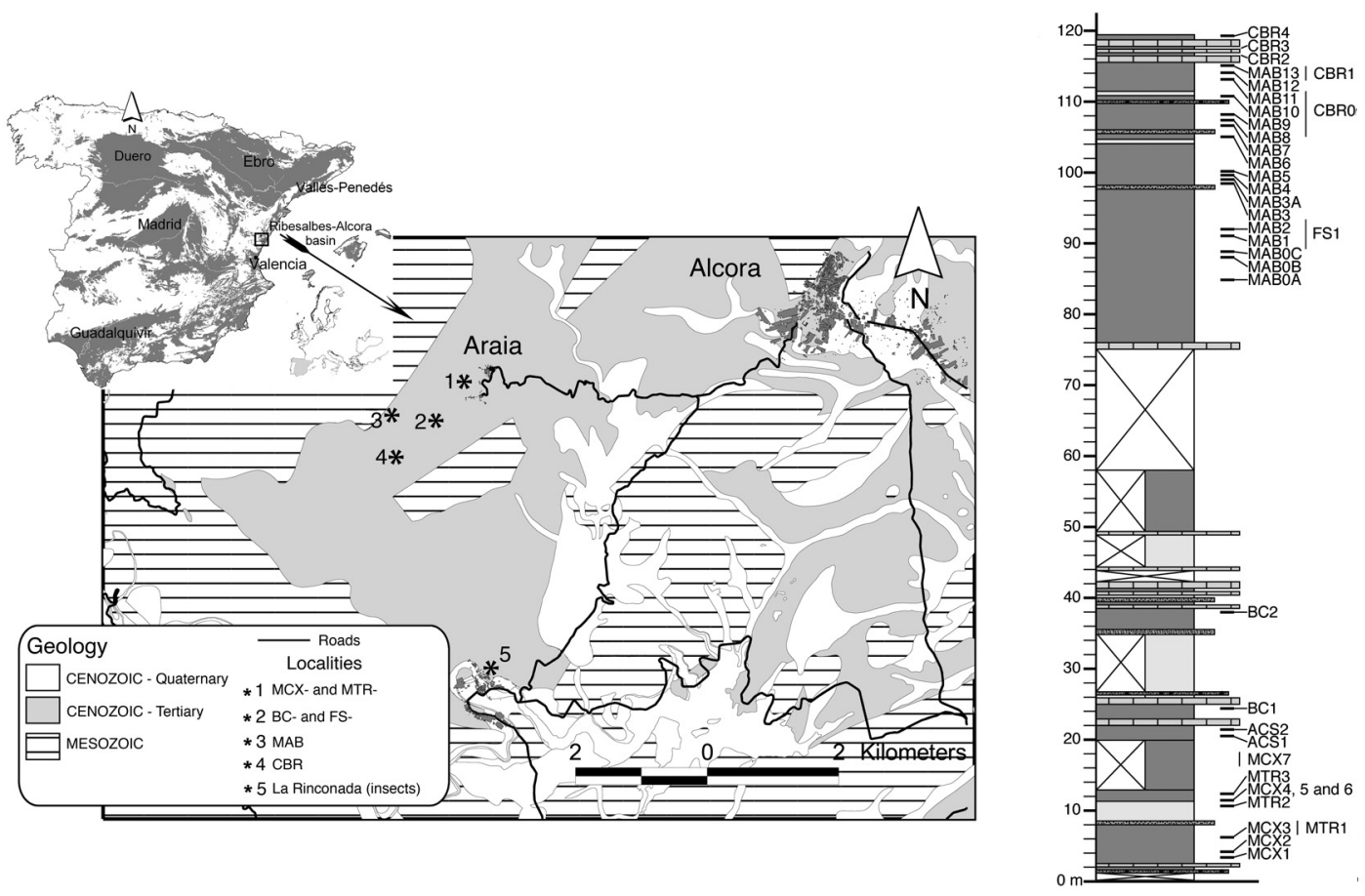

FIGURE 1. Left: Spanish Cenozoic basins, with location of the Ribesalbes-Alcora Basin and the schematic distribution of sediments and the position of the studied fossil sites. Right: Synthetic column of the Campisano ravine with the situation of the studied sites. ACS: Araia Cantera Sud; BC: Barranc de Campisano; CBR: Corral de Brisca; FS: Foieta la Sarra; MAB: Mas d'Antolino B; MCX: Mas dels Coixos; MTR: Mas de Torner. La Rinconada is the classical FossilLagerstätte site with remains of insects, plants and amphibians. Modified from Crespo et al. (2018; 2019a).

SYSTEMATIC PALAEONTOLOGY

Class MAMMALIA Linnaeus, 1758

Order SORICOMORPHA Gregory, 1910

Family SORICIDAE Fischer, 1814

Subfamily CROCIDOSORICINAE Reumer, 1987

Tribe OLIGOSORICINI Gureev, 1971

Genus OLIGOSOREX Kretzoi, 1959

Oligosorex thauensis (Crochet, 1975)

Figure 2.1-2.24

Localities. MTR2, MTR3, MAB0A, MAB0B, MAB3, MAB5, MAB6, MAB7, MAB11, MAB11B, CBR0D, CBROE and CBROG.

Material. MTR2: $1 \mathrm{~m} 2$; MTR3: $1 \mathrm{~m} 2$; MAB0A: 1 M1; MAB0B: $2 \mathrm{~m} 1,1 \mathrm{~m} 2,1 \mathrm{I}, 1 \mathrm{M} 2,1 \mathrm{M} 3$; MAB3: 1 a2, $1 \mathrm{~m} 2,1 \mathrm{~m} 3,3 \mathrm{I}, 1 \mathrm{~A} 1,1 \mathrm{P} 4,4 \mathrm{M} 1,6 \mathrm{M} 2,1 \mathrm{M} 3$; MAB5: 2 i, 3 m2, 4 m3, 1 I, 4 P4, 2 M1, 2 M2, 6 M3; MAB6: 1 m3; MAB7: 1 M1/M2; MAB11: $1 \mathrm{i}, 1$ p4, 1 $\mathrm{m} 1,3 \mathrm{~m} 2,1 \mathrm{~m} 3,3$ fragmented mandibles , $2 \mathrm{I}, 1$ P4, 2 M1, 2 M2; MAB11B: $1 \mathrm{~m} 1,1 \mathrm{M} 1,1 \mathrm{M} 2$; CBROD: $1 \mathrm{~m} 1,1 \mathrm{~m} 3,1 \mathrm{I}, 1 \mathrm{M} 1$; CBROE: $1 \mathrm{M} 1,1$ M2; CBROG: 1 M2.

Measurements. Table 2

\section{Description}

Mandible. A fragmented remains of mandible is found. The most complete fragment has the m2-3 locus and partial deep internal temporal fossa, with an angulous antero-lower corner of it.

i. Tooth slightly hook-shaped in lateral view. A narrow basin is present along the lingual side of the crown, whereas on the labial side there are small basins at the anterior and posterior parts. There is a narrow cingulid in the lingual side. The tooth is strongly bicuspulate, with both cuspules similar in size. The posterior margin of the lingual side is concave, the labial margin is convex and both have a small cingulid. The incisor from MAB11 has lower cuspids.

a2. The a2 has one root. The occlusal outline is almost triangular. The single cusp is positioned in the anterior third of the tooth; it is Y-shaped with two crests directed towards the posterolingual and posterolabial flanks, the latter crest is more developed than the former one. The lingual side is more developed, and the base of the crown is lower than the labial side. The sharp anterior ridge is protruding. The cingulid is high, wide, and it encircles the whole tooth except for the end of the anterior ridge; 

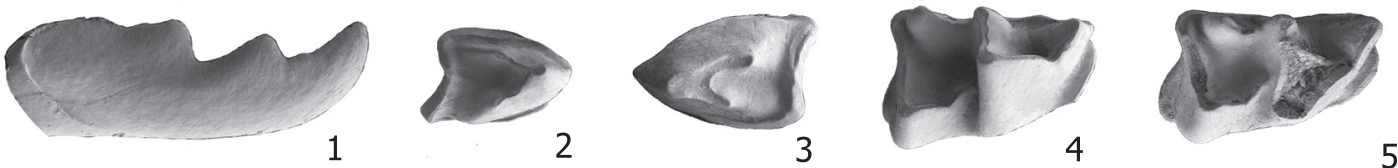

5

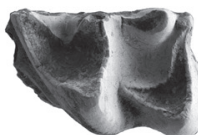

6

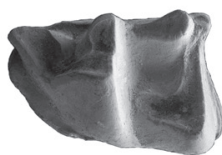

7
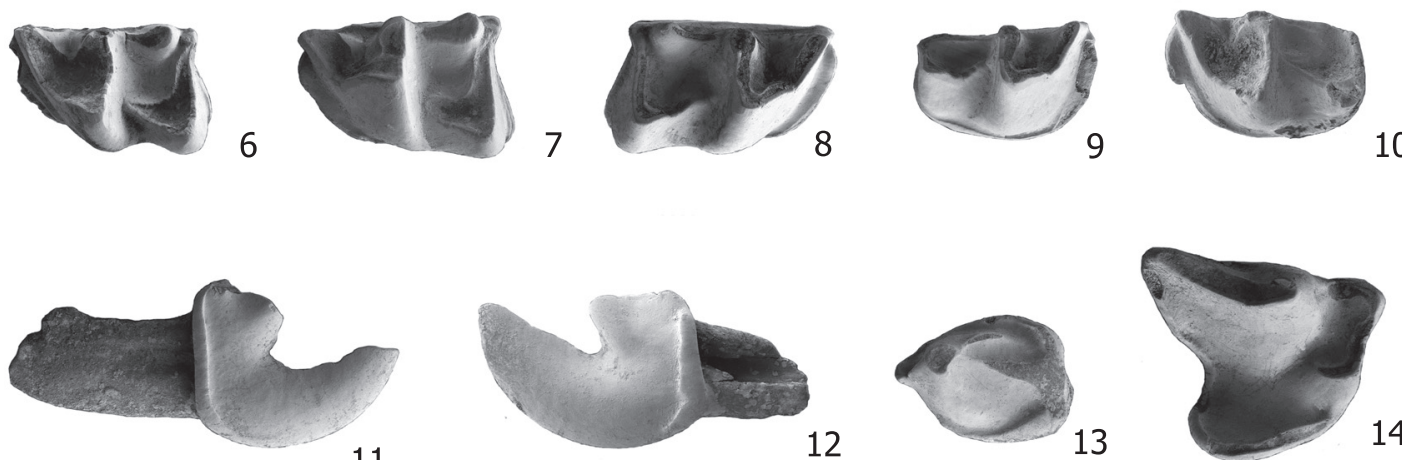

11
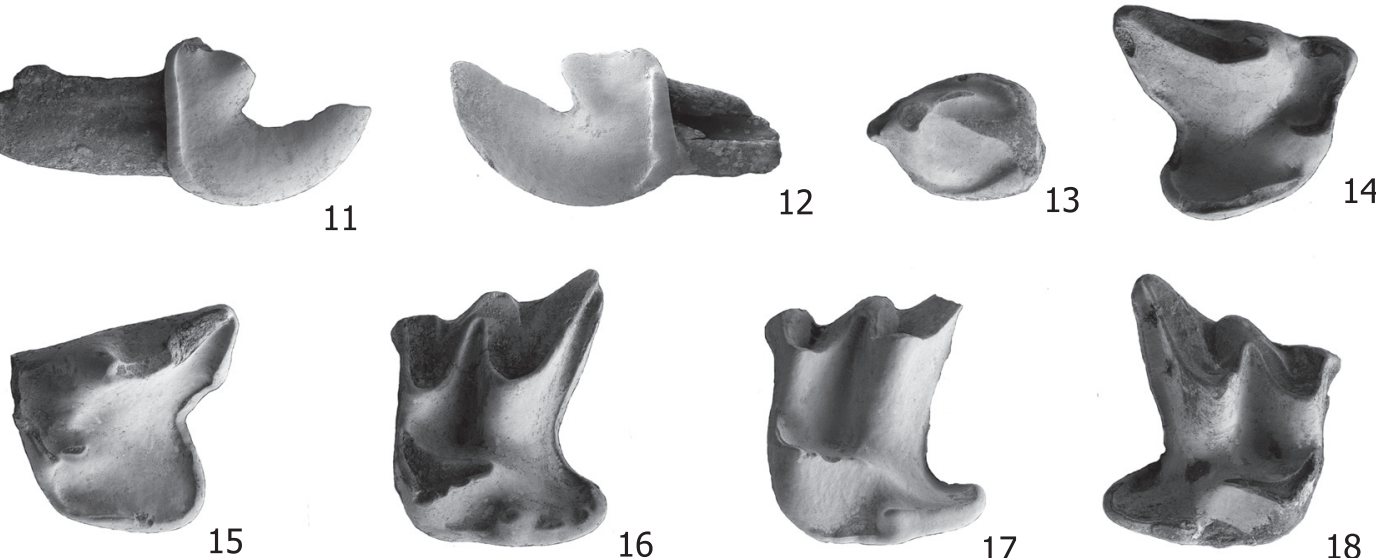

17
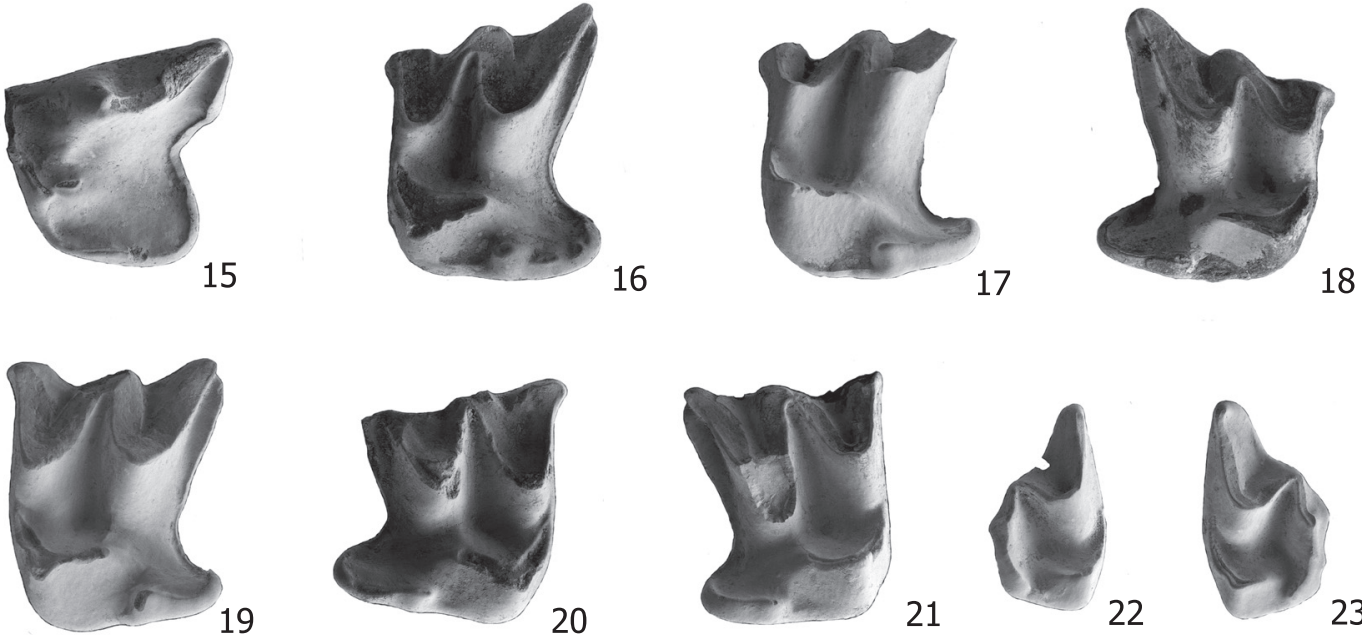

21
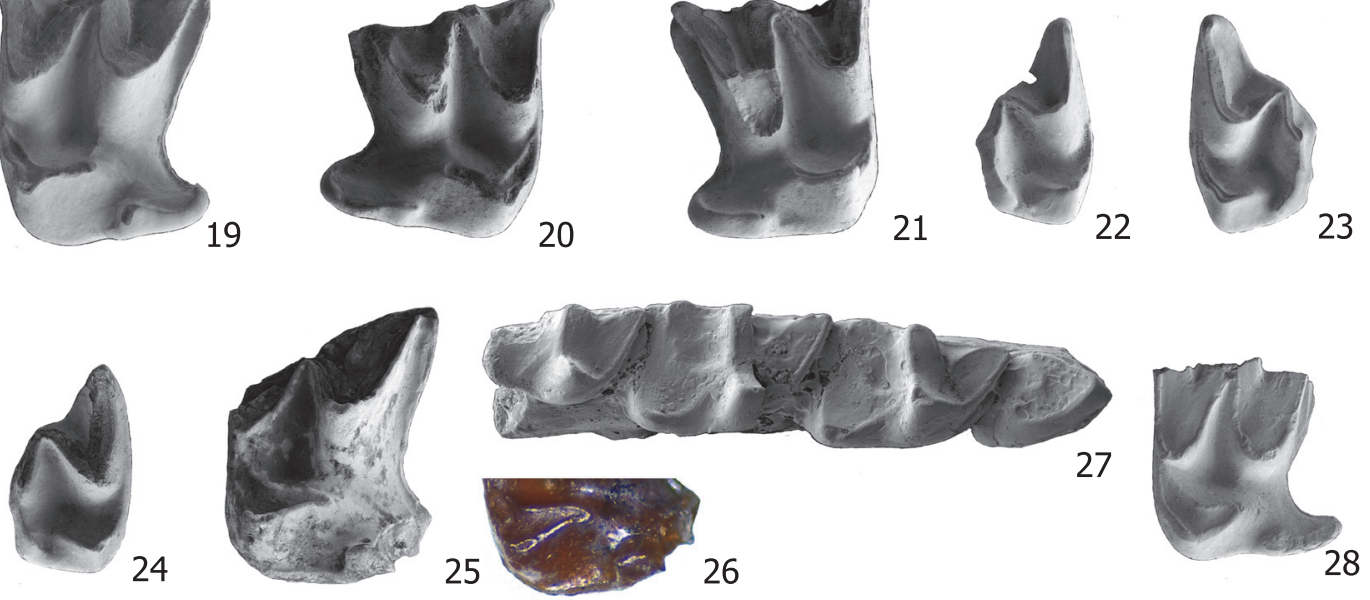

FIGURE 2. Teeth of the family Soricidae from the Ribesalbes-Alcora Basin. Oligosorex thauensis: 1- Right $\mathrm{i}$ (lingual view, MAB5-435); 2- Right a2 (MAB3-780); 3- Left p4 (MAB11-134); 4- Right m1 (MAB0B-42); 5- Right m1 (MAB11B9); 6- Left m2 (MTR2-203); 7- Left m1 (MAB3-868); 8- Right m2 (MAB5-376); 9- Right m3 (MAB5-889); 10- Left m3 (MAB6-10); 11- Right I (MAB0B-48); 12- Left I (MAB3-868); 13- Left A1 (MAB3-796); 14- Right P4 (MAB3-777); 15Left P4 (MAB5-390); 16- Left M1 (MAB5-387); 17- Left M1 (MAB11B-6); 18- Right M1 (CBR0E-5); 19- Left M2 (MAB0A-82); 20- Right M2 (MAB5-144); 21- Right M2 (CBR0G-3); 22- Right M3 (MAB0B-45); 23- Left M3 (MAB3713); 24- Right M3 (MAB5-731); cf. Soricella discrepans: 25- Left M1 (FS1-69); 26- detail in optical microscope of the FS1-69 to remark the lingual cingulum poorly observed in SEM photography. Paenelimnoecus micromorphus: 27Right mandible with p4-m3 (BC1-196); 28- Left M1 (BC1-161). Scale bar equals $1 \mathrm{~mm}$. 
TABLE 2. Measurements of the teeth of soricids and heterosoricids from the Ribesalbes-Alcora Basin. AW: Anterior width; BL: Buccal length; H: Height; L: Length; LL: Lingual length; LT: Length of the talon; PE: Posterior emargination; PW: Posterior width; TAW: Talonid length; TRW: Trigonid length; W: Width.

\begin{tabular}{|c|c|c|c|c|c|c|}
\hline Element & Site & Measurement & $\mathbf{n}$ & Min. & Med. & Max. \\
\hline \multicolumn{7}{|c|}{ Oligosorex thauensis } \\
\hline \multirow[t]{4}{*}{$\mathrm{i}$} & MAB5 & L & 1 & & 2.10 & \\
\hline & & W & 2 & 0.58 & 0.63 & 0.68 \\
\hline & MAB11 & L & 1 & & 1.81 & \\
\hline & & W & 1 & & 0.79 & \\
\hline \multirow[t]{2}{*}{ a2 } & MAB3 & $\mathrm{L}$ & 1 & & 0.84 & \\
\hline & & W & 1 & & 0.58 & \\
\hline \multirow[t]{2}{*}{$\mathrm{p} 4$} & MAB11 & L & 1 & & 1.06 & \\
\hline & & W & 1 & & 0.69 & \\
\hline \multirow[t]{15}{*}{$\mathrm{m} 1$} & MABOB & L & 2 & 1.17 & 1.20 & 1.22 \\
\hline & & TRW & 2 & 0.76 & 0.78 & 0.80 \\
\hline & & TALW & 2 & 0.81 & 0.82 & 0.83 \\
\hline & MAB5 & L & 1 & & 1.24 & \\
\hline & & TRW & 1 & & 0.76 & \\
\hline & & TALW & 1 & & 0.77 & \\
\hline & MAB11 & $\mathrm{L}$ & 2 & 1.21 & 1.24 & 1.27 \\
\hline & & TRW & 2 & 0.78 & 0,79 & 0.80 \\
\hline & & TALW & 3 & 0.77 & 0.79 & 0.81 \\
\hline & MAB11B & L & 1 & & 1.23 & \\
\hline & & TRW & 1 & & 0.61 & \\
\hline & & TALW & 1 & & 0.74 & \\
\hline & CBROD & L & 1 & & 1.28 & \\
\hline & & TRW & 1 & & 0.79 & \\
\hline & & TALW & 1 & & 0.86 & \\
\hline \multirow[t]{13}{*}{$\mathrm{m} 2$} & MTR2 & L & 1 & & 1.16 & \\
\hline & & TRW & 1 & & 0.71 & \\
\hline & & TALW & 1 & & 0.76 & \\
\hline & МАВ0B & TALW & 1 & & 0.8 & \\
\hline & MAB3 & L & 1 & & 1.17 & \\
\hline & & TRW & 1 & & 0.72 & \\
\hline & & TALW & 1 & & 0.79 & \\
\hline & MAB5 & L & 1 & & 1.10 & \\
\hline & & TRW & 1 & & 0.69 & \\
\hline & & TALW & 1 & & 0.69 & \\
\hline & MAB11 & L & 1 & & 1.28 & \\
\hline & & TRW & 1 & & 0.73 & \\
\hline & & TALW & 1 & & 0.84 & \\
\hline \multirow[t]{2}{*}{$\mathrm{m} 1,2$} & MTR3 & TALW & 1 & & 0.76 & \\
\hline & MAB11A & TALW & 1 & & 0.81 & \\
\hline \multirow[t]{4}{*}{ m3 } & MAB3 & L & 1 & & 0.91 & \\
\hline & & W & 1 & & 0.75 & \\
\hline & MAB5 & L & 4 & 0.96 & 1.01 & 1.05 \\
\hline & & W & 3 & 0.62 & 0.70 & 0.77 \\
\hline
\end{tabular}


TABLE 2 (continued).

\begin{tabular}{|c|c|c|c|c|c|c|}
\hline Element & Site & Measurement & $\mathbf{n}$ & Min. & Med. & Max. \\
\hline & MAB11 & L & 1 & & 1.06 & \\
\hline & & W & 1 & & 0.73 & \\
\hline & CBROD & L & 1 & & 1.04 & \\
\hline & & W & 1 & & 0.64 & \\
\hline \multirow[t]{12}{*}{ I } & MABOB & L & 1 & & 1.18 & \\
\hline & & LT & 1 & & 0.52 & \\
\hline & & $\mathrm{H}$ & 1 & & 0.96 & \\
\hline & MAB3 & Length & 1 & & 1.13 & \\
\hline & & LT & 2 & 0.51 & 0.53 & 0.55 \\
\hline & & $\mathrm{H}$ & 3 & 0.85 & 0.89 & 0.93 \\
\hline & MAB5 & Length & 1 & & 1.23 & \\
\hline & & LT & 1 & & 0.60 & \\
\hline & & $\mathrm{H}$ & 1 & & 0.85 & \\
\hline & MAB11 & Length & 1 & & 1.23 & \\
\hline & & LT & 2 & 0.55 & 0.58 & 0.61 \\
\hline & & $\mathrm{H}$ & 2 & 0.91 & 0.93 & 0.94 \\
\hline \multirow[t]{2}{*}{$\mathrm{A} 1$} & MAB3 & Length & 1 & & 0.99 & \\
\hline & & Width & 1 & & 0.73 & \\
\hline \multirow[t]{9}{*}{$\mathrm{P} 4$} & MAB3 & $\mathrm{BL}$ & 1 & & 1.44 & \\
\hline & & Width & 1 & & 1.08 & \\
\hline & & PE & 1 & & 0.90 & \\
\hline & & LL & 1 & & 0.95 & \\
\hline & MAB5 & $\mathrm{BL}$ & 4 & 1.36 & 1.39 & 1.44 \\
\hline & & Width & 2 & 1.18 & 1.23 & 1.28 \\
\hline & & PE & 2 & 0.78 & 0.85 & 0.91 \\
\hline & & LL & 1 & & 0.91 & \\
\hline & MAB11 & $\mathrm{BL}$ & 1 & & 1.58 & \\
\hline \multirow[t]{12}{*}{ M1 } & MAB3 & $\mathrm{BL}$ & 2 & 1.21 & 1.23 & 1.24 \\
\hline & & PE & 1 & & 0.94 & \\
\hline & & AW & 2 & 1.16 & 1.22 & 1.27 \\
\hline & MAB5 & $\mathrm{BL}$ & 2 & 1.18 & 1.19 & 1.19 \\
\hline & & PE & 2 & 0.89 & 0.92 & 0.94 \\
\hline & & LL & 2 & 1.16 & 1.18 & 1.19 \\
\hline & & AW & 2 & 1.19 & 1.23 & 1.27 \\
\hline & & PW & 2 & 1.49 & 1.50 & 1.51 \\
\hline & MAB11 & $B L$ & 1 & & 1.27 & \\
\hline & MAB11B & PE & 1 & & 0.89 & \\
\hline & & LL & 1 & & 1.20 & \\
\hline & & AW & 1 & & 1.29 & \\
\hline \multirow[t]{5}{*}{ M2 } & MABOA & $\mathrm{BL}$ & 1 & & 1.20 & \\
\hline & & PE & 1 & & 0.92 & \\
\hline & & LL & 1 & & 1.12 & \\
\hline & & AW & 1 & & 1.48 & \\
\hline & & PW & 1 & & 1.48 & \\
\hline
\end{tabular}


TABLE 2 (continued).

\begin{tabular}{|c|c|c|c|c|c|c|}
\hline Element & Site & Measurement & $\mathbf{n}$ & Min. & Med. & Max. \\
\hline & MAB3 & $\mathrm{BL}$ & 2 & 1.15 & 1.19 & 1.22 \\
\hline & & PE & 3 & 0.89 & 0.91 & 0.93 \\
\hline & & LL & 2 & 1.08 & 1.15 & 1.22 \\
\hline & & AW & 1 & & 1.43 & \\
\hline & MAB5 & $\mathrm{BL}$ & 1 & & 1.07 & \\
\hline & & PE & 1 & & 0.89 & \\
\hline & & LL & 1 & & 1.22 & \\
\hline & & AW & 2 & 1.30 & 1.33 & 1.35 \\
\hline & CBR0G & $\mathrm{BL}$ & 1 & & 1.13 & \\
\hline & & PE & 1 & & 0.84 & \\
\hline & & LL & 1 & & 1.06 & \\
\hline & & AW & 1 & & 1.39 & \\
\hline & & PW & 1 & & 1.02 & \\
\hline \multirow[t]{6}{*}{ M3 } & MABOB & Length & 1 & & 0.68 & \\
\hline & & Width & 1 & & 1.14 & \\
\hline & MAB3 & Length & 1 & & 0.71 & \\
\hline & & Width & 1 & & 1.23 & \\
\hline & MAB5 & Length & 4 & 0.77 & 0.83 & 0.92 \\
\hline & & Width & 3 & 0.96 & 1.03 & 1.10 \\
\hline \multicolumn{7}{|c|}{ cf. Soricella discrepans } \\
\hline M1 & FS1 & $\mathrm{PE}$ & 1 & & 1.02 & \\
\hline \multicolumn{7}{|c|}{ Paenelimnoecus micromorphus } \\
\hline $\mathrm{i}$ & $\mathrm{BC} 1$ & Width & 1 & & 0.54 & \\
\hline \multirow[t]{2}{*}{ p4 } & $\mathrm{BC} 1$ & Length & 1 & & 0.67 & \\
\hline & & Width & 1 & & 0.55 & \\
\hline \multirow[t]{3}{*}{$\mathrm{m} 1$} & $\mathrm{BC} 1$ & $\mathrm{~L}$ & 2 & 1.01 & 1.05 & 1.09 \\
\hline & & TRW & 2 & 0.67 & 0.67 & 0.67 \\
\hline & & TAW & 2 & 0.72 & 0.73 & 0.73 \\
\hline \multirow[t]{3}{*}{$\mathrm{m} 2$} & $\mathrm{BC} 1$ & $\mathrm{~L}$ & 2 & 1.07 & 1.09 & 1.10 \\
\hline & & TRW & 2 & 0.69 & 0.70 & 0.70 \\
\hline & & TAW & 2 & 0.73 & 0.74 & 0.74 \\
\hline \multirow[t]{2}{*}{ m3 } & $\mathrm{BC} 1$ & $\mathrm{~L}$ & 2 & 0.89 & 0.90 & 0.91 \\
\hline & & W & 2 & 0.52 & 0.56 & 0.60 \\
\hline \multirow[t]{2}{*}{ I } & $\mathrm{BC} 1$ & $\mathrm{LT}$ & 1 & & 0.49 & \\
\hline & & $\mathrm{H}$ & 1 & & 0.82 & \\
\hline \multirow[t]{2}{*}{ M2 } & $\mathrm{BC} 1$ & PE & 1 & & 0.79 & \\
\hline & & LL & 1 & & 1.05 & \\
\hline \multicolumn{7}{|c|}{ Heterosorex neumayrianus } \\
\hline \multirow[t]{2}{*}{$\mathrm{i}$} & MAB3 & $\mathrm{L}$ & 1 & & 6.25 & \\
\hline & & W & 1 & & 1.80 & \\
\hline \multirow[t]{2}{*}{ a3 } & $\mathrm{BC} 1$ & L & 1 & & 0.65 & \\
\hline & & W & 1 & & 0.76 & \\
\hline \multirow[t]{2}{*}{ p4 } & MAB3 & $L$ & 1 & & 1.03 & \\
\hline & & W & 1 & & 0.98 & \\
\hline
\end{tabular}


TABLE 2 (continued).

\begin{tabular}{|c|c|c|c|c|c|c|}
\hline Element & Site & Measurement & $n$ & Min. & Med. & Max. \\
\hline \multirow[t]{6}{*}{$\mathrm{m} 1$} & MTR2 & $\mathrm{L}$ & 1 & & 1.99 & \\
\hline & & TRW & 1 & & 1.36 & \\
\hline & & TAW & 1 & & 1.40 & \\
\hline & MAB3 & $\mathrm{L}$ & 1 & & 1.87 & \\
\hline & & TRW & 2 & 1.26 & 1.27 & 1.27 \\
\hline & & TAW & 1 & & 1.32 & \\
\hline \multirow[t]{3}{*}{$\mathrm{m} 2$} & MAB3 & L & 1 & & 1.60 & \\
\hline & & TRW & 1 & & 1.37 & \\
\hline & & TAW & 1 & & 1.29 & \\
\hline $\mathrm{m} 1,2$ & MAB3 & TAW & 1 & & 1.39 & \\
\hline \multirow[t]{3}{*}{1} & MAB3 & L & 1 & & 2.83 & \\
\hline & & LT & 1 & & 0.93 & \\
\hline & & $\mathrm{H}$ & 1 & & 1.87 & \\
\hline \multirow[t]{6}{*}{ A1 } & MABOB & L & 2 & 1.65 & 1.67 & 1.68 \\
\hline & & w & 2 & 1.31 & 1.37 & 1.43 \\
\hline & MAB3 & L & 1 & & 1.74 & \\
\hline & & w & 1 & & 1.35 & \\
\hline & MAB5 & L & 2 & 1.66 & 1.74 & 1.81 \\
\hline & & w & 2 & 1.36 & 1.39 & 1.43 \\
\hline \multirow[t]{2}{*}{ A2 } & MAB3 & $\mathrm{L}$ & 3 & 1.08 & 1.13 & 1.19 \\
\hline & & W & 3 & 0.90 & 0.93 & 0.97 \\
\hline \multirow[t]{2}{*}{ A3 } & MTR2 & L & 1 & & 1.00 & \\
\hline & & W & 1 & & 0.81 & \\
\hline \multirow[t]{2}{*}{ A4 } & MABOB & L & 1 & & 0.92 & \\
\hline & & W & 1 & & 0.61 & \\
\hline \multirow[t]{4}{*}{ P4 } & MAB5 & $B L$ & 2 & 1.54 & 1.57 & 1.59 \\
\hline & & $w$ & 2 & 1.53 & 1.54 & 1.55 \\
\hline & & PE & 1 & & 1.24 & \\
\hline & & LL & 1 & & 1.12 & \\
\hline \multirow[t]{5}{*}{ M1 } & MAB3 & $\mathrm{BL}$ & 1 & & 1.73 & \\
\hline & & PE & 1 & & 1.80 & \\
\hline & & LL & 1 & & 1.75 & \\
\hline & & AW & 1 & & 1.80 & \\
\hline & & PW & 1 & & 1.82 & \\
\hline \multirow[t]{2}{*}{ M3 } & MAB11B & $\mathrm{L}$ & 1 & & 0.82 & \\
\hline & & W & 1 & & 1.33 & \\
\hline
\end{tabular}

it is most pronounced in the posterolingual and posterolabial corners.

p4. The p4 has two roots. It is similar to the a2 but larger. The posterolingual crest is nearly as long as the posterior one.

$\mathbf{m 1}$. Overall, the $\mathrm{m} 1$ is more subtriangular than the $\mathrm{m} 2$. The talonid is wider than the trigonid. The anterior cingulid is wide. The paraconid is larger, but lower than the metaconid. The paralophid is $\mathrm{V}$ shaped. The protoconid is the largest and highest cuspid. The protolophid is high, short and Vshaped. The trigonid basin is closed by a cingulid. The talonid basin is deep. The entoconid is connected to the metaconid by a straight entocristid. The entoconid is high and separated from the end of the entostylid. The hypolophid is high and 
straight and is not connected to the entoconid. At the base of the entostylid starts a small cingulid that ends in the anterior cingulid. The hypoconid is well developed. The oblique cristid ends near to the protoconid and is S-shaped in occlusal view. The hypoflexid is well developed and the lingual basin is present.

$\mathbf{m} 2$. Similar to the $\mathrm{m} 1$ but with a more rectangular overall shape. The talonid is slightly wider than the trigonid but both are similar in length. The postentoconid valley and hypoconulid are smaller than the $\mathrm{m} 1$. The paraconid is as high as the metaconid. The protolophid is larger than in the $\mathrm{m} 1$. The entoconid is lower than in the $\mathrm{m} 1$. The oblique cristid terminates close to the protoconid.

m3. The trigonid basin is open lingually. The talonid is reduced, being markedly smaller and narrower than the trigonid. The entoconid is reduced and connected to the metaconid by a straight entocristid. The hypolophid is straight and connected to the entoconid. The hypoconid is well developed. The oblique cristid ends approximately between the protoconid and the metaconid under the protolophid. The lingual cingulid is narrow.

I. The basal margin is semicircular; the principal cusp is large. The talon is a triangular double cusp. The concavity between the principal cusp and the talon is large. The posterior margin is concave on both lingual and labial sides; the lingual concavity is easily visible. The principal cusp wears a ridge running down to the talon base and a blunt lingual ridge; they border a wide and shallow valley. The talon has two cusps, one of them (the labial), or both, well developed, but the labial cusp is always more pronounced than the lingual one. The crest that prolonges it posteriorly is connected to the cingulum. Between the two cusps, there is a valley of variable width. The cingulum starts at the end of the lingual talon cusp and becomes larger lingually, forming a long crest alongside the posterior margin on the labial side and ending next to the most basal point.

A1. The tooth has one root. The overall outline is almost triangular. The single cusp is positioned in the anterior third of the tooth; it has three directed backwards, one central, more developed than the others and two lateral crests oriented towards the posterolingual and posterolabial flanks. The crown of the lingual side is slightly lower than the labial side. The sharp anterior crest is wide and protruding. The cingulum is large, wide and encircles the whole tooth; it is most pronounced in the anterior, posterolingual and posterolabial corners.
P4. The tooth has three roots, one lingual and two labial. The occlusal outline is rather trapezoidal, with a concave posterior side and the lingual corner curved. The paracone is large and conical, but strongly enlarged along its ridge and slightly bending posteriorly. The parastyle is angular and placed in the anterolabial end of the tooth. There ia a wide valley between the paracone and the parastyle. A small lingual cingulum is present. The protocone is larger, but lower than the parastyle. The hypocone is an enlargement of the cingulum of the hypoconical flange. This cingulum is connected to the posterior cingulum, which is well developed. The posterior emargination is well marked. The P4 from MAB3 has a narrower talon.

M1. The tooth is subtrapezoidal in occlusal view. The paracone and the metacone are $\mathrm{W}$-shaped and bend more posteriorly than the M2, the second cusp is higher than first one. The preparacrista connects to the parastyle and the last cusp has a style that runs towards the posterior part. The postparacrista and the premetacrista are connected via the mesostyle, which is strongly directed backwards. The postmetacrista is long and includes the metastyle. The preprotocrista is short and ends at the anterior margin of the paracone; the protoconule is absent. The metaloph runs towards the posterior part of the hypoconical flange, but it does not contact them and shows a free end. A narrow basin is present between the metaloph and the metacone. The trigon basin is large and deep. The development of the lingual cingulum is variable; it is situated in the postero-lingual part of the protocone. The development of the hypocone is very variable, it may be conical, isolated, fused with the hypoloph, a strong ridge around the hypoconal flange. In the posterior part of the hypocone, the hypoloph may have one or two more or less developed accessory cuspules. The hypoloph borders a shallow basin and fuses to the cingulum in the posterior emargination. The talon shows a relatively vertical position. The posterior cingulum is wide and well developed and it ends in the posterior flank of the metastyle.

M2. The M2 is similar to the M1, but the paracone and the metacone are less bent posteriorly. The preparacrista shows a posterior spur. The postmetacrista is shorter than in the M1. A very weak protoconule is present.

M3. The occlusal outline is subtriangular. The paracone is the highest cusp. The parastyle is a thickening of the preparacrista. The postparacrista connects posteriorly to the mesostyle, which is included in the ridge connecting the first crest with 
the premetacrista. The metacone is the smallest cusp, and constitutes a little posterior enlargement of the premetacrista and postmetacrista The postmetacrista is short and narrow and either it ends at the postero-lingual side of the tooth or it connects with the metaloph. The protocone is flattened and looks angular-shaped (not rounded) in the labial and lingual sides. The metaloph ends in the trigonid basin. The preprotocrista is long and ends at the anterior base of the paracone; there is no protoconule. The trigon basin is wide and deep.

\section{Remarks}

Due to the absence of complete mandibles, the taxonomy of the small-sized shrews from the lower Miocene is very complicated, since its classification is based on the number of antemolars, in species with non-specialized morphology and of similar size (Van den Hoek Ostende, 2003). On the other hand, although this group has conservative molars, some taxonomic discrimination is possible based on small morphological details (Van den Hoek Ostende, 2003; Engesser, 2009; Klietmann et al., 2014). The material studied belongs to one species by the low morphological and size variability of the same teeth in the differents sites.

Furió et al. (2007) split the subfamily Crocidosoricinae in three tribes: the tribe Myosoricini (which includes the lower-middle Miocene genus Miosorex), the tribe Crocidosoricini (with Crocidosorex or Carposorex, typical early Miocene forms) and the tribe Oligosoricini, represented in the early Miocene by the genera Oligosorex, Miocrocidosorex, Soricella, Florinia, Clapasorex, Ulmensia and Lartetium. The material here described cannot be attributed to the tribe Myosoricini, because their members have the talonid basin of the $\mathrm{m} 3$ reduced. Similarly, the studied material cannot be allocated to the tribe Crocidosoricini, since in this group the p4 shows posterolabial crest more developed than the posterolingual one. Therefore, the studied material can be ascribed to the Oligosoricini.

Miosorex desnoyersianus from Petersbuch 28 (Klietmann et al., 2014) and Sansan (Engesser, 2009) differs by: the lower incisor is curved and the cuspids are similar in size; the lower molars in having a less developed entoconid and lingual cingulid; a wider talonid of the $\mathrm{m1}, 2$; a longer entocristid, and shorter trigonid of the $\mathrm{m} 3$. With respect to the upper molars, the material in study has a general compressed shape and the hypocone is better developed.
Comparing with the different genera of the tribe Oligosoricini, the studied material differs from Florinia and Miocrocidosorex which have a very reduced talonid in the m3 (Lopatin, 2004; Klietmann et al., 2014). It also differs from Clapasorex since this genus is characterized by compressed antero-posterior upper molars, a well-developed lingual cingulum and a $\mathrm{m} 3$ with a reduced talonid (Hugueney et al., 2012). The genus Soricella is excluded because it is the only oligosoricine with a contact between the hypolophid and the entoconid hence without a postentoconid valley (Doben-Florin, 1964). Ulmensia can be discarded as well because in this genus the posterolabial edge of the protoconid forms a crest that contacts to the middle of the labial cingulum (Hugueney and Maridet, 2011). The comparison with the genus Lartetium is more problematic: some authors suggest it is a synonym of Oligosorex and propose its revision (Klietmann et al., 2014), whereas some others recognize both genera as closely related (Hugueney et al., 2015). Even so we can rule out this genus because Lartetium has a well-developed hypocone in the P4 and M1 (Hugueney et al., 2015), and an absent or poorly developed entocristid (Ziegler, 1989; Doukas and Van den Hoek Ostende, 2006).

The genus Oligosorex occurs in the Iberian Peninsula until the beginning of MN5 (Van der Meulen et al., 2012). This genus comprises three species: Oligosorex antiquus (Pomel, 1853), Oligosorex reumeri van den Hoek Ostende, 2001 and $O$. thauensis. Oligosorex antiquus is the oldest and biggest species. It shows less-developed labial cingulids than in the studied localities, and the $\mathrm{m} 1$ and $\mathrm{m} 2$ are similar in size (Van den Hoek Ostende, 2001b; Hugueney and Maridet, 2011). Oligosorex reumeri only appears in MN3 from Turkey, and it differs from our material in its interrupted labial cingulid, $\mathrm{m} 1$ and $\mathrm{m} 2$ with a similar size and in a less developed hypocone (Van den Hoek Ostende, 2001b).

The studied material is morphologically very similar to O. thauensis from the Ramblian of the Daroca-Calamocha area, including the highly variable hypocone in the upper molars (Van den Hoek Ostende, 2003). The specimens from the Ribesalbes-Alcora Basin only differ from the Ramblian populations in the $\mathrm{P} 4$, which is morphologically closer to Clapasorex alvarezae Van den Hoek Ostende, 2003 than the P4 attributed to O. thauensis by this author. Initially, the presence of $C$. alvarezae can be discarded because the rest of teeth have the same characteristics of $O$. thauensis, with the exception of the P4. When comparing sizes 
with others populations of O. thauensis (Van den Hoek Ostende, 2003; Van den Hoek Ostende et al., 2017), it can be noted that the p4 and the $M 2$ in Ribesalbes-Alcora are larger whereas the $\mathrm{m} 1$, the $\mathrm{m} 2$, the $\mathrm{P} 4$ and the $\mathrm{M} 1$ are similar in size. The ratio AW/PW in the M1 are very stable in all specimens (0.79-0.84), while in the M2 is 1-1.02.

The remains of this species from the Ribesalbes-Alcora Basin represent its last known occurrence in the fossil record.

Genus SORICELLA Doben-Florin, 1964

cf. Soricella discrepans Doben-Florin, 1964

Figure 2.25-2.26

Locality. FS1

Material. FS1: $1 \mathrm{M} 1$

Measurements. Table 2

Description

M1. Although the tooth is broken its subtrapezoidal shape can still be discerned in occlusal view. The paracone and the metacone are W-shaped and bend backwards, the second cusp being higher than the first. The (also broken) preparacrista joins the parastyle. The postparacrista and the premetacrista are connected via the mesostyle. The postmetacrista is long and the metastyle is broken. The preprotocrista is short and ends at the lingual margin of the paracone; the protoconule is absent. The metaloph runs posteriorly towards the hypoconical flange and ends free before attaining it; a narrow basin is present between the metaloph and the metacone. The trigon basin is large and deep. The lingual cingulum is narrow and runs from the anterolingual to the posterolingual part of the protocone. The hypocone is conical and constitutes the starting point of the hypoloph. The hypoconal flange is broken up to the hypocone. The hypoconal flange shows a relativelly vertical position. The posterior cingulum is well developed and wide, and it ends in the posterior flank of the metastyle.

\section{Remarks}

This is the second soricid present in the Araia material. This tooth has only been recovered in site FS1 and is characterized by a large size (Table 2, the only measurement is the largest of the material in study) as well as the strong development lingual cingulum that surrounds the protocone in the M1. This morphology is characteristic of the species Soricella discrepans, a monospecific genus recorded in Europe during the time spanning from MN2 to MN4. It is in contrast only recorded during but only in MN2 in the Iberian Peninsula (Van den Hoek Ostende, 2003; Van den Hoek Ostende and
Furió, 2005; Klietmann et al., 2014). The absence of the lower molars, the principal diagnostic tooth, only enables us to leave this taxon in doubtful nomenclature. This species is the largest one in the European assemblages of the family soricidae in the early Miocene (Van den Hoek Ostende, 2003; Klietmann et al., 2014) and it is the only soricid from the early Miocene with the lingual cingulum developed (detail in Figure 2.26).

Subfamily ALLOSORICINAE Fejfar, 1966

Genus PAENELIMNOECUS Baudelot, 1972

Paenelimnoecus micromorphus (Doben-Florin 1964)

Figure 2.27-2.28

Locality. BC1

Material. BC1: $1 \mathrm{i}, 2$ mandibles fragments (p4-m3 and $\mathrm{m} 1-\mathrm{m} 3), 2 \mathrm{I}$ and $1 \mathrm{M} 2$.

Measurements. Table 2

Description

Mandible. the mental foramen is under the trigonid of the $\mathrm{m} 1$.

i. The tooth is broken. Narrow basins are present along the crown on the lingual and labial side, with two narrow cingulids. The tooth is bicuspulate; the second cuspule is higher. The posterior margin of the lingual side is concave; the labial margin is convex.

p4. The tooth has one root, and it is worn. The overall outline is almost triangular. The single cusp is positioned in the anterior third of the tooth; from this cusp two crests are directed towards the posterolingual and the posterolabial flanks, thus resulting in a V-shape; the posterolabial crest is more developed than the posterolingual one. The lingual side is more developed and the base of the crown is lower than the labial side. The sharp anterior ridge is large and protruding. The cingulid is long, narrow and it encircles the whole tooth; it is most pronounced in the posterolingual and the posterolabial corners.

$\mathrm{m} 1$. The overall shape of the $\mathrm{m} 1$ resembles a rectangle with the anterolabial corner cut off in a curve. The talonid is wider and shorter than the trigonid. The anterior cingulid is wide. The paraconid is lower than the metaconid. The paralophid is Vshaped in lateral view. The protoconid is the largest and highest cuspid. The protolophid is high. The lingual cingulid is well developed and closes the trigonid basin. The talonid basin is narrow. The entoconid is connected to the metaconid with a short and straight entocristid. The entoconid is poorly developed and separated from the end of the entostylid. The hypolophid is high and straight; at the base of this crest there is a small posterior cingulid. 
The hypoconid is well developed. The oblique cristid ends under the protoconid. The hypoflexid is poorly developed and the lingual basin is absent. The lingual cingulid is very narrow and short or absent.

$\mathbf{m} 2$. The $\mathrm{m} 2$ is similar to the $\mathrm{m} 1$ but with a more rectangular overall shape. The talonid is wider than the trigonid but both are of similar length. The protolophid is lower than in the $\mathrm{m} 1$.

$\mathrm{m} 3$. This tooth is similar to the $\mathrm{m} 2$ but smaller and with a very reduced talonid. The protolophid is as high as the metaconid. The lingual cingulid is narrow. The entoconid is poorly developed and connected to the metaconid with a short and straight entocristid. The entoconid is connected to the hypolophid: the entostylid is not present. The hypolophid is short and rounded. The hypoconid is poorly developed. The lingual cingulid and the lingual basin are either very narrow and small or even absent in one specimen.

I. The basal margin is semicircular; the principal cusp is large. The concave part between the principal cusp and the talon is large. The posterior margin is concave on both the lingual and the labial side; the lingual concavity is wide. The principal cusp is broken. The talon is triangular, a cusp initially directed forwards and later bent down towards the occlusal side, the labial cusp is more pronounced and the lingual is very small, between them, there is a clear valley. The crest that prolongs them posteriorly is connected to the cingulum. The cingulum starts at the end of the lingual talon cusp and becomes thicker in lingual direction, forming a large crest alongside the posterior margin on the labial side and ending next to the most basal point.

M2. The tooth has a subtrapezoidal shape in occlusal view, its labial part is broken. The paracone and the metacone are U-shaped and bend slightly backwards. The postparacrista and the premetacrista are connected via the mesostyle, which is slightly displaced to the posterior part. The preprotocrista ends at the anterior margin of the paracone; the protoconule is absent. The metaloph runs towards the posterior part of the tooth, but ends before reaching the hypoconical flange. The trigon basin is large. A poorly developed lingual cingulum is present. The hypocone is a small enlargement of the hypoloph, which is a strong ridge around the hypoconal flange; it borders a shallow basin and fuses with the cingulum in the posterior emargination. The hypoconical flange is relatively vertical. The posterior cingulum is wide on the metacone side and very narrow on the hypoconal flange and connects the hypoloph to the metastyle flank.

\section{Remarks}

The Araia material is characterised by its small size, by the V-shaped p4, the V-shaped trigonid, an extreme reduction of the entoconid of the $\mathrm{m} 1$ and $\mathrm{m} 2$ and the extreme reduction of the $\mathrm{m} 3$ talonid (Van den Hoek Ostende et al., 2009). We can discard the similar genus Florinia because it has a p4 with "soricine" morphology, its entoconid is more developed, the talonid of the $\mathrm{m} 3$ is rounded and it only has entocristid. In addition, the lower molars have a complete lingual cingulid that connects the paraconid with the hypoconulid. The talon of the upper molars is shorter.

The morphologies observed herein are typical for the genus Paenelimnoecus (Klietmann et al., 2014). During the European early Miocene, two species have been defined, namely $P$. micromorphus in MN3-MN4 from Central Europe and the related species Paenelimnoecus truyolsi in MN4MN5 from the Iberian Peninsula (Van den Hoek Ostende et al., 2009). The latter authors remark that the principal difference between both species is the presence in P. micromorphus of a one-rooted $\mathrm{V}$-shaped $\mathrm{p} 4$. This morphology is more primitive and has a "crocidosoricine" form, while this element in P. truyolsi is "soricine", with the reduced lingual crest and two roots.

The p4 from BC1 has "crocidosoricine" morphology, similar to $P$. micromorphus. The entoconid and entocrestid in the lower molars are less developed than in $P$. truyolsi and similar to the material of $P$. micromorphus from Peterbuch 28. The M2 has a narrower talon than the two species (Klietmann et al., 2014). The material from BC1 is slightly larger than both species and closer to other later species like Paenelimnoecus crouzeli Baudelot, 1972. The upper molar is the smallest M2 in our soricid material. Consequently, we think that the material under study can be determined as $P$. micromorphus, which would constitute the first site of this species in the Iberian Peninsula.

\section{Family HETEROSORICIDAE (Viret y Zapfe 1951) Genus HETEROSOREX Gaillard, 1915 Heterosorex neumayrianus (Schlosser, 1887) Figure 3}

Localities. MTR2, BC1, MAB0B, MAB3, MAB5 MAB8, MAB11B and CBR0B.

Material. MTR2: $1 \mathrm{~m} 1,2 \mathrm{~A} 3$; $\mathrm{BC} 1: 1 \mathrm{a} 3,1 \mathrm{~m} 3$; MAB0B: 2 A1, 1 A4; MAB3: 1 i, 1 p4, 3 m1, 2 m2, 1 m3, 1 I, 1A1, 3 A2, 1 M1; MAB5: 1 i, 1 I, 2 A1, 1 A3, 2 P4, 1 M3; MAB8: 1 I; MAB11B: 1 M3; CBR0B: 1 i. 

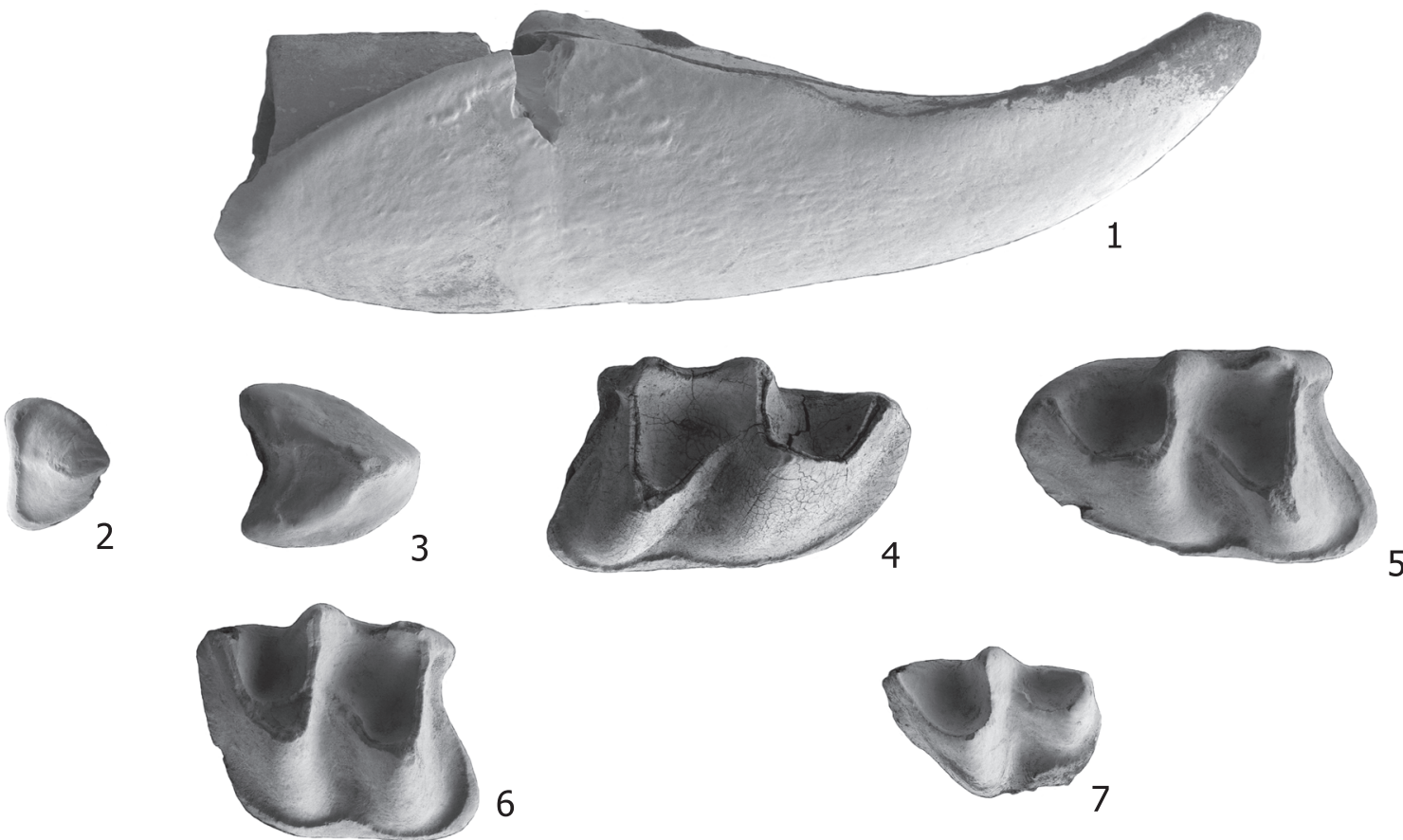

4
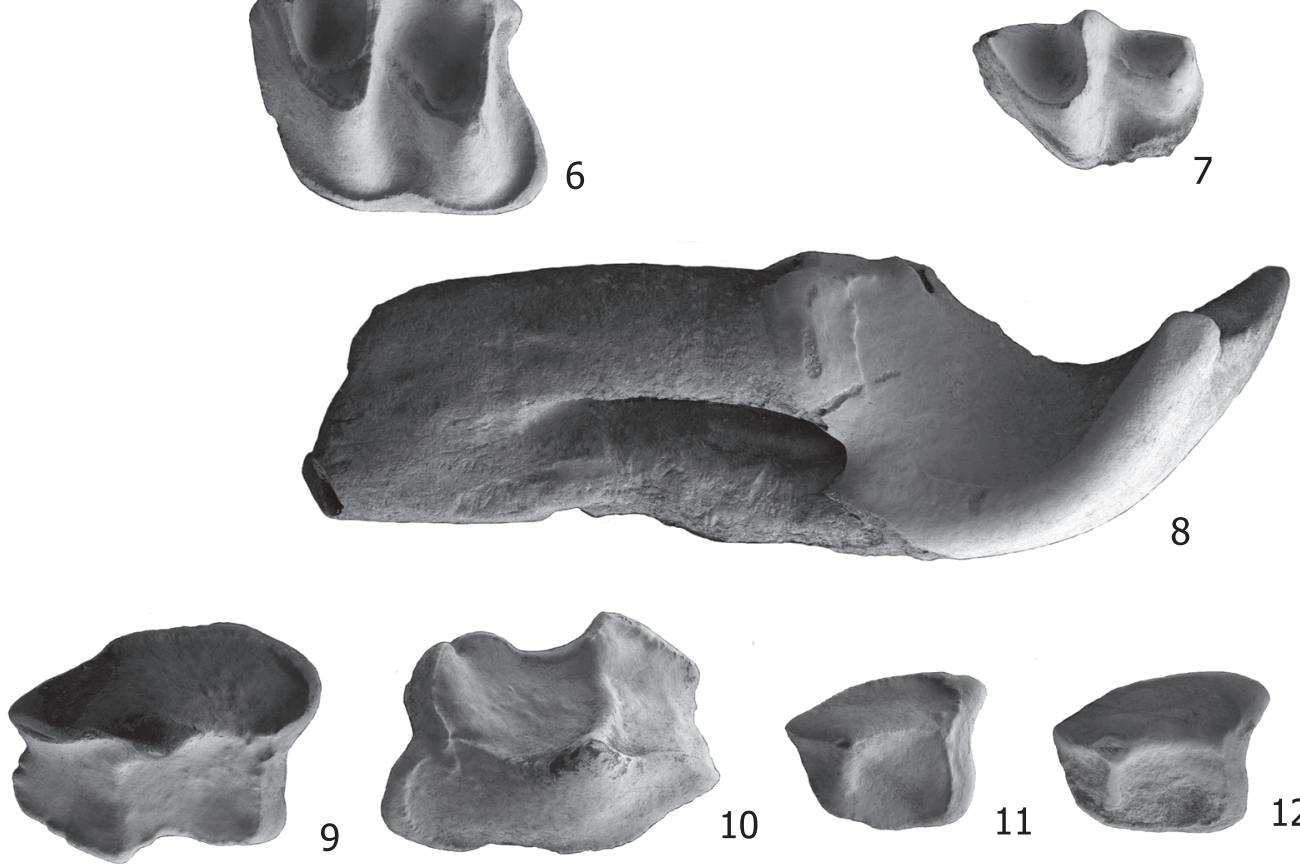

\section{6}
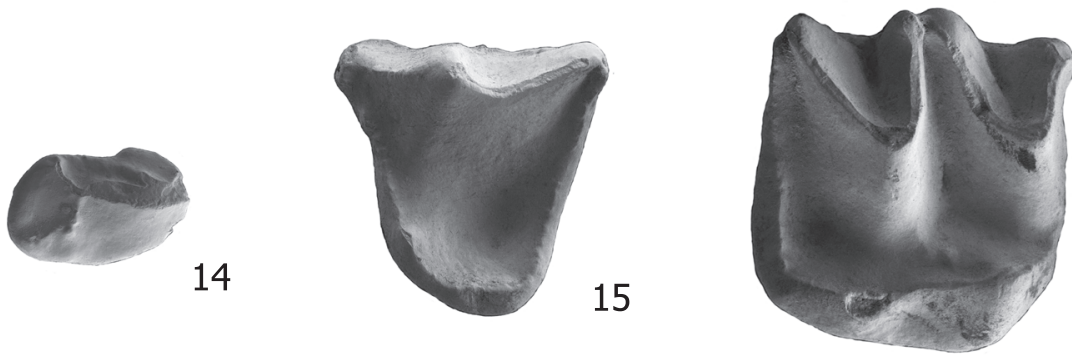

16

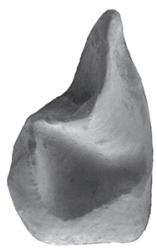

17

FIGURE 3. Teeth of the family Heterosoricidae from the Ribesalbes-Alcora Basin. Heterosorex neumayrianus: 1Right i (labial view, MAB3-864); 2- Right a3 (BC1-191); 3- Right p4 (MAB3-792); 4- Right m1 (MTR2-195); 5- Left m1 (MAB3-862); 6- Left m2 (MAB3-861); 7- Left m3 (BC1-192); 8- Right I (MAB3-807); 9- Left A1 (MAB0B-46); 10- Left A1 (MAB5-769); 11- Right A2 (MAB3-786); 12- Left A2 (MAB3-784); 13- Left A3 (MTR2-190); 14- Right A4 (MAB0B52); 15- Left P4 (MAB5-749); 16- Right M1 (MAB3-700); 17- Right M3 (MAB11B-8). Scale bar equals $1 \mathrm{~mm}$. 


\section{Measurements. Table 2}

\section{Description}

i. The incisor is long, curved and subtriangular in frontal view. The surface is somewhat wrinkled. The superior part of the tooth has a platform, on the labial side it presents a cingulid with two small cuspids; another cingulid is present under this platform. The labial surface has a small upper depression with a posterior cingulid that continues up to the middle of the lingual side. The root is stout and shows a very deep groove along the lingual side.

a3. The outline of the occlusal surface is subtriangular; the anterior side is tip-shaped whereas the posterior side is emarginated. The antemolar is wider than long. The top of the main cuspid lies just on the centre of the antemolar and is slightly inclined to the lingual side. A centrocrista runs backwards over the top of the main cuspid, from the anterior part towards the posterolabial side, and there is another crest directed towards the lingual side between the top and the postero-lingual margin. The cingulid is well developed and wide around the tooth but absent on the anterior side.

p4. The p4 is similar to the a3 but larger, as long as wide, and with a poorly developed anterior cingulid. $\mathbf{m 1}$. The occlusal outline is sub-rectangular. The talonid is somewhat wider than the trigonid. The protoconid is higher than the metaconid. The paraconid is bulky and somewhat lower. The paralophid is V-shaped. The trigonid basin is wide whereas the talonid basin is narrow. The entoconid and the hypoconid are similar in size. The oblique cristid ends at the middle of the protoconidmetaconid crest. The hypoflexid and the lingual basin are well developed. The hypolophid is connected to the entoconid. The entostylid protrudes on the posterlo-lingual corner. The cingulid is continuous along the anterior, labial and posterior sides; the anterior part of the cingulid is wide. The posterior cingulid is very well developed and protrudes on the posterior side.

$\mathbf{m} 2$. The $\mathrm{m} 2$ is similar to the $\mathrm{m} 1$ but with a more rectangular outline. The trigonid and the talonid are wide, the second is slightly wider than the first. The metaconid and the protoconid are similar in size. The paraconid is somewhat lower. The hypoconid is higher than the entoconid. The entocristid is poorly developed. The oblique cristid ends near the metaconid. The entostylid is isolated of the hypolophid. The cingulid is continuous and well developed along the anterior to posterior sides.

$\mathrm{m} 3$. The $\mathrm{m} 3$ is similar to the $\mathrm{m} 2$, but smaller. In addition, the talonid is reduced and less rectangu- lar, the trigonid basin is wider than the talonid basin and the labial cingulid is wide. The hypolophid is very reduced. The cingulid on the labial basin is wide and has a cuspule.

I. The I1 is large with a moderate hook; in the lingual side the hook is more marked. The enamel is somewhat wrinkled. The apex is fissident, the central cusp is smaller than the labial cusp. The talon bears a cusp. There is a shallow depression with a rather abrupt edge on the labial side of the talon. The supra labial part of the tooth has a well-developed cingulum. The root is stout. It shows a very deep groove along the lingual side.

A1. The A1 is similar to the A2 but larger and with a sub-rectangular occlusal surface. There is an anterolingual protuberance in occlusal view. The antemolar is somewhat longer than wide. The centrocrista is better developed on the anterior side than the on posterior one, and there is a lingually directed crest between the top and a protruding cingulum in the lingual flange; this crest may be well or poorly developed. The latter crest divides the lingual side in two concave surfaces; the edge of the posterior surface is convex in occlusal view. Some specimens show both the labial and lingual cingulum poorly developed, others only the labial cingulum, and finally, others a well-developed posterior cingulum. Under the posterolingual cingulum, the tooth has a protruding platform. The anterior cingulum is lacking. The anterior part of the A4 is irregular. The tooth has one root.

A2. The $A 2$ is similar to the $A 3$, but larger.

A3. The outline of the occlusal surface is subquadrate, and bigger than in the A4. The enamel is somewhat wrinkled. The posterior side is emarginated. The antemolar is as long as wide. The top of the main cusp is in the anterio part of the tooth and is slightly inclined to the lingual side. A centrocrista runs over the top of the main cusp, from the anterolabial part in a posterolabial direction, and there is a lingually directed crest between the top and the lingual margin. A small protrusion in occlusal view is present in the lingual side. A well-developed cingulum is present around the tooth except on the anterior side. The tooth has one root.

A4. The occlusal outline is sub-elliptical. The enamel is slightly wrinkled. The posterior side is emarginated and there is an anterolingual protuberance in occlusal view. The antemolar is longer than wide. The anterolingual part of the tooth is protrudent. A centrocrista runs over the top of the main cusp, in the middle of the posterior face of the cusp is divided in two crests. A poorly developed 
cingulum is present around the tooth. The tooth has one root.

P4. The occlusal outline is sub-triangular. The parastyle is a small cusp joined to the start of the lingual cingulum. The paracone is high. The posterocrista is curved from the tip of the paracone to the postero-labial corner of the premolar. The lingual cingulum is well developed and runs from the parastyle to the postero-labial corner of the premolar; the protocone and the hypocone are thickenings of the lingual cingulum; the protocone is located on the antero-lingual part of the tooth, and the hypocone on the lingual side. The cingulum borders a deep basin. The tooth has three roots.

M1. The occlusal outline is sub-quadrate; the tooth is as wide as long. The anterior side is slightly curved anteriorly and has a hint of a cingulum. The parastyle is rounded. The paracone and the metacone are high. The anterior and posterior crests of these cusps form sharp ridges. The mesostyle is deeply divided, the end of the postparacrista is sharp while the extreme of the premetacrista is round. The trigon basin is very deep. The protocone is well-developed and distincly lower than the paracone. The hypocone is poorly developed. The anterior arm of the protocone ends at the base of the paracone. A central small arm of the protocone ends at the base of the metacone. A crest connects the protocone and the hypocone, which is only a thickening of the postero-lingual cingulum. This cingulum reaches the metastyle, and encloses a wide valley. The metastyle is sharp. The posterior side is straight.

M3. The occlusal outline is sub-triangular. The paracone is the highest cusp. The preparacrista runs labially to the parastyle, which is a thickening of the preparacrista. A poorly developed anterior cingulum is present. The postparacrista connects posteriorly to the mesostyle, which is included in the ridge connecting the postparacrista and the premetacrista. The metacone is the smallest cusp and consists in a small posterior enlargement of the premetacrista and postmetacrista, which are both strong ridges. The postmetacrista is connected to the metastyle. The protocone is lower than the paracone and higher than metacone. It is flattened in both the labial and the lingual side. The poorly developed preprotocrista ends at the base of the paracone. There is no protoconule. The trigon basin is wide and deep.

\section{Remarks}

The fossil record of heterosoricids from the early Miocene of Europe is limited to two genera,
Heterosorex and Dinosorex (Furió et al., 2015). The former differs from the latter in many dental and mandibular characters. Heterosorex is characterized by an undivided masseteric fossa and a cuspulate lower incisor, the posterior border of which extends to the trigonid of $\mathrm{m} 1$. In contrast, Dinosorex is characterized by a divided fossa masseterica and an acuspid lower incisor, the posterior border of which extends to $\mathrm{m} 1$ (Ziegler, 1999). No mandible has been recovered in the studied sites, but the isolated teeth differ clearly from Dinosorex (Van den Hoek Ostende, 1995). Indeed, cuspulated lower incisives, triangular P4 and poorly developed lingual cuspids in upper molars, are morphologies typical for Heterosorex (Smith and Van den Hoek Ostende, 2006; Klietmann et al., 2014; Furió et al., 2015).

Heterosorex is common in Central Europe, but unusual in the Iberian Peninsula. Generally, the fossil remains are scarce, not studied, dubious or in need of revision. Agustí et al. (1988) describe one upper molar of $H$. subsequens from the locality of Mas de Antolino 2. The tooth fits well with the material described here. Nowadays the species $H$. subsequens is a subspecies of $H$. neumayrianus, similarly to the original description provided by Doben-Florin (1964).

The genus Heterosorex comprises four species: $H$. neumayrianus, Heterosorex ruemkeae Doukas, 1986, Heterosorex wangi Storch and Qiu, 1991 and Heterosorex delphinensis Gaillard, 1915. The last species only differs of $H$. neumayrianus in a few mandibular characters and the reduction of the antemolars. $H$. delphinensis is the most derived species and the last record of this genus, it has been only reported in the site of La Grive Saint Alban, but the original karstic fissure is lost and their precise age is unknown (Hugueney et al., 2012). H. ruemkeae differs from our material by its larger size and its weak cingulum in the P4 (Doukas, 1986). $H$. wangi is smaller, with a postcrestid in the lower molars that does not reach directly the entoconid and with more reduced antemolars and lower incisives (Storch and Qiu, 1991).

The species $H$. neumayrianus is divided in to three subspecies, which can be distinguished by the degree of reduction of the antemolars, the size of the molars and the position of the mental foramen. The different subspecies are probably ancestor-descendant (Klietmann et al., 2014). Heterosorex neumayrianus neumayrianus is the most primitive form and is characterized by the anterior position of the mental foramen (Klietmann et al., 2014). Heterosorex neumayrianus under- 
goes a size increase during MN3. The forms of the late MN3 are ascribed to $H$. n. subsequens (Doben-Florin, 1964). During MN4 H. neumayrianus decreased in size again (H. n. aff. subsequens) (Ziegler and Fahlbusch, 1986).

In addition to size, the different forms can be distinguished by the degree of antemolar reduction. The only way to distinguish the different subspecies is on the basis of the mental foramen position, because size difference is only slightly appreciable in $H$. $n$. aff. subsequens from MN4 of Germany, which might invalidate the classification in diverse subspecies described above (DobenFlorin, 1964; Ziegler, 1989; Ziegler and Fahlbusch, 1989; Klietmann et al., 2014). In Araia, the size of the upper molars is intermediate between $H$. $n$. aff. neumayrianus and $H$. n. subsequens, so our material is here ascribed to none of them and it might belong to a differentiated population with intermediate size between the two subspecies.

Another feature, absent in the populations of $H$. neumayrianus of MN4 in Central and Western Europe but present in our material is the divided mesostyle. This character appears in H. ruemkeae (Doukas, 1986), where the mesostyle shows a slight division and is more pronounced in some species of the genera Dinosorex and Quercysorex (Ziegler, 1999). In addition, the material from Araia and Les Cases de la Valenciana show a better developed hypocone than the populations from Central Europe although never as prominent as in the genus Dinosorex (Engesser, 2009; JovellsVaquè et al., 2018).

\section{DISCUSSION}

\section{Paleocology}

Abundant and highly diverse assemblages of shrews have been traditionally considered as indicative of an humid (Reumer, 1995; Minwer-Barakat et al., 2010; Furió et al., 2011) and wooded habitat (Van den Hoek Ostende, 2001b). In the early-middle Miocene, this diversity is particularly high in Central Europe, and somewhat lower in France, although some of the Central European genera, such as Paenelimnoecus and Soricella, occasionally occur in southern latitudes (Van den Hoek Ostende et al., 2009; 2016). According to the literature (Van den Hoek Ostende, 2001b; 2003; Klietmann et al., 2015), Oligosorex prefers dry environments. Nevertheless, its presence in almost all sites in Araia suggests that this genus was probably relatively independent from water resources. After the isotopic analysis was realised by Rios
(2013) and the paleoecological inferences was realised by Crespo (2017), we can observe a variability in the dries/humids environments along the sequence of Araia. The abundance of shrews in Araia can be interpreted as an indicator of a wooded environment (Table 3). The genus Paenelimnoecus, which occurs only in BC1, generally lives in rather warm and wet habitats (RzebikKowalska, 1994). However, Popov (2003) states that at least Paenelimnoecus pannonicus (Kormos, 1934), may have preferred dry environments with more or less open bush zones. The presence of this genus might indicate a warmer, drier and more open site in comparison with the rest of the basin. These conditions are less favourable for Oligosorex thauensis and permit the establishment of the small shrew $P$. micromorphus, as it is the case in Petersbuch 28. In the last site the species $P$. micromorphus might have been displaced by biggersized soricids. Similar situation occurs with the extant species Sorex minutus Linnaeus, 1766, which is limited by the presence of the larger Sorex araneus Linnaeus, 1758 (Klietmann et al., 2014).

The palaeocology of the extinct heterosoricids is poorly known (Furió et al., 2015). Doukas (1986) and Van den Hoek Ostende (2001b) consider Heterosorex and Dinosorex as forest dwellers, because these genera are found together with other wood dwellers and in lignitous sites. The only complete heterosoricid skeleton belongs to Lusosorex thaishanensis Storch and Qiu, 2004, and it shows fossorial adaptations, which probably involves that it lived in wet and soft lands (Storch and Qiu, 2004). Furió et al. (2011) consider Dinosorex a prefers humid habitats than Heterosorex. This is confirmed by the high abundance of Dinosorex in Hambach 6C, a lignitous site (Ziegler and Mörs, 2000). Therefore, it might be assumed that Heterosorex is a forest dweller (Klietmann, 2013) and prefers moist environments, although in a lesser degree than Dinosorex. This can explain the co-occurrence of both genera in the middle Miocene of Central Europe: probably, while Heterosorex might have been a more open dweller, Dinosorex might have preferred more forest habitats (Van den Hoek Ostende, 1995; Klietmann et al., 2015).

Nevertheless, these interpretations might be erroneous since Heterosorex occurs in all sites in Ribesalbes-Alcora, no matter how humid or wooded the sites were, at least according to the preliminary isotopic study (Ríos, 2013) and a preliminar palaeocological interpretation (Crespo, 2017). In addition, the scarcity of heterosoricids 
TABLE 3. Percentages of frequency (\%) of soricids, heterosoricids, dimylids, talpids and erinaceids found in the Araia sections. Only represented are the sites intensively sampled with more than 50 teeth, the number in parentheses next to the locality name represents the number of mammal teeth found at this site, and the number in parenthesis next to the frequency is the percentatge of the family with respect to the mammals teeth found in the sites studied from Ribesalbes-Alcora Basin (modified from Crespo et al., 2019).

\begin{tabular}{cccccc}
\hline Locality & Soricids & Heterosoricids & Dimylids & Talpids & Erinaceids \\
\hline CBR0B (56) & 0 & $16.8(1.8)$ & 0 & $83.2(8.9)$ & 0 \\
MAB11 (145) & $52(11.9)$ & 0 & $3.1(0.7)$ & $24(5.5)$ & $20.9(4.8)$ \\
MAB5 (874) & $12.3(2.7)$ & $4.1(0.9)$ & $51.4(11.3)$ & $15.5(3.4)$ & $16.8(3.7)$ \\
MAB3 (807) & $25.5(2.4)$ & $18.1(1.7)$ & 0 & $24.5(2.3)$ & $31.9(3)$ \\
FS1 (63) & $25(1.6)$ & 0 & 0 & $25(1.6)$ & $50(3.2)$ \\
MAB0B (75) & $33.3(8)$ & $16.7(4)$ & 0 & $38.7(9.3)$ & $11.3(2.7)$ \\
MAB0A (80) & $33.3(1.3)$ & 0 & 0 & $33.3(1.3)$ & $33.3(1.3)$ \\
BC1 (180) & $48.3(7.2)$ & $7.4(1.1)$ & $7.4(1.1)$ & $29.5(4.4)$ & $7.4(1.1)$ \\
MTR2 (187) & $5.8(0.5)$ & $18.6(1.6)$ & 0 & $50(4.3)$ & $25.6(2.2)$ \\
MCX3 (132) & 0 & 0 & 0 & $9.5(0.8)$ & $90.5(7.6)$ \\
\hline
\end{tabular}

could be due to competition with the dimylids in the sites in study, as suggested by their relative scarcity in all sites where the dimylids are present (Table 3).

\section{Biostratigraphy}

The soricids and heterosoricids are rarely used in biostratigraphy (Klietmann et al., 2014). While the shrews are the dominant insectivores in current faunas, this was not the case in the earlymiddle Miocene (Van den Hoek Ostende et al., 2016). Their high abundance in some karstic fissures from Central Europe made possible detailed taxonomic studies, while the Iberian fossil record almost exclusively consists of isolated teeth. This complicates a confident taxonomic ascription and their use in biostratigraphy (Van den Hoek Ostende et al., 2016). Notwithstanding, an indeterminate species of Oligosorex has been recorded until the middle of MN5 zone in the Calatayud-Montalbán Basin (Van der Meulen et al., 2012). Oligosorex thauensis, has been previously reported until the middle of MN3 zone in the Iberian Peninsula (Furió et al., 2007). Consequently, the record of Araia demonstrates the last known appearance of this species.

The genus Soricella has been recorded between zones MN2 and MN6 (Furió et al., 2007). The fossil record in the Iberian Peninsula of the genus Paenelimnoecus in the Iberian Peninsula is poor (Van den Hoek Ostende et al., 2009). The genus first appears in the Iberian Peninsula in the local zone A (MN3; early Miocene) and is not recorded after the local zone $\mathrm{E}$ (MN5; middle Miocene) (Van den Hoek Ostende et al., 2009; 2016;
2017) (a second reappearance of this genus occurs from MN12 until MN16 (Minwer-Barakat et al., 2010; Van Dam et al., 2014; Furió and Agustí, 2017; Piñero et al., 2018). Although, in the central area of the Iberian Peninsula, it is represented by $P$. truyolsi, whereas the species represented in Araia is $P$. micromorphus, which is typical from Central Europe. This fact shows that $P$. micromorphus is a transient taxon and was probably better adapted to particular environmental conditions present in BC1.

The genus Heterosorex is typical from the early Miocene, and its record starts in the late Oligocene, until the middle Miocene locality of La Grive Saint Alban, where it is considered a Lazarus taxon (Brunet et al., 1981; Ziegler, 1989; Van den Hoek Ostende et al., 2016). Before MN4, this genus is almost exclusively limited to Central Europe. It has only been reported as a transient form in MN2 of Ramblar 1, Cetina de Aragón and Navarrete del Río (Calatayud-Montalbán Basin) and MN3 of Alto de Ballester 1 (Rubielos de Mora Basin) (Van den Hoek Ostende and Furió, 2005; Van den Hoek Ostende et al., 2017). Since the local zone Ca from MN4 until its extinction at the end of the local zone $\mathrm{Cb}$, its presence is generalized. This genus appears in the Daroca-Calamocha area, in the Ribesalbes-Alcora Basin and in several sites from different iberian basins such as the Vallès-Penedès (Les Cases de la Valenciana); Teruel (Montalvos 2); Magro (Buñol) and Madrid (O'Donnell) (Agustí et al., 1988; Robles et al., 1991; Van der Meulen et al., 2012; Hordijk et al., 2015; Van den Hoek Ostende, et al. 2016; JovellsVaquè et al., 2018; this paper). Heterosorex might 
have been the victim of the expansion of grasslands and the climate change since the early-middle Miocene, in the Langhian, with droughts lasting up to six months in the Iberian Peninsula (PostigoMijarra et al., 2009; Barrón et al., 2010). On the other hand, even though the closely related Dinosorex migrated in to Europe in the early Miocene, it did not appear in the Iberian Peninsula before the end of the middle Miocene. This genus, in Spain, only appears in the Vallès-Penedès Basin, this basin is characterized by environmental conditions similar to typical Central European of the end of the early Miocene (Furió et al., 2015)

\section{CONCLUSIONS}

The studies of soricids and heterosoricids from the Iberian Peninsula are rare and mostly limited to faunal lists. This stresses the importance of systematic research on these groups. The Ribesalbes-Alcora Basin, with continental sequences similar in age to those of the Calatayud-Montalbán area (local biozones $\mathrm{Ca}$ and $\mathrm{Cb}, \mathrm{MN} 4$, early Miocene), has yielded a relative abundant fauna of soricids. Oligosorex thauensis is dominant in almost all studied assemblages. If this species is absent then cf. Soricella discrepans and Paenelimnoecus micromorphus occur. On the other hand, Heterosorex neumayrianus is relatively abundant except where dimylids are present - and has been recorded in all studied sites with an rich sample of mammal remains.

The soricid $O$. thauensis is at present the youngest Oligosorex species described. In fact, the specimens from Araia represent the last known occurrence of this species, which prolonges its biostratigraphical record up to the end of the early Miocene. If the taxonomic ascription of cf. Soricella discrepans is confirmed, first site in MN4 in the lberian Peninsula with this species, previously only known in MN3 in the Iberian Peninsula or MN4 in
Central Europe. In addition, Paenelimnoecus micromorphus, a typical Central European taxon, is found for the first time in the Iberian Peninsula. On the other hand the heterosoricid Heterosorex neumayrianus is a typical form of MN4 from the Iberian Peninsula. In summary, $O$. thauensis and $H$. neumayrianus represent resident species in the Iberian Peninsula, while $P$. micromorphus and probably Soricella discrepans were a new immigrant at this time in Spain.

The high relative abundance of Oligosorex thauensis and Heterosorex neumayrianus suggests that both species were eurytopic, whereas cf. Soricella discrepans and Paenelimnoecus micromorphus were more probably stenotopic, in Ribesalbes-Alcora Basin. The presence of $O$. thauensis, excludes the occurrence of the other two soricid species, a fact also observed in current faunas and in the site of Petersbuch 28 . On the other hand, $H$. neumayrianus occurs in all kind of sites in the studied sections, which permits us to consider this species as more eurytopic than previously thought by the anterior authors. Its apparent mutual exclusion with the dimylids in the Ribesalbes-Alcora Basin probably indicates some kind of competition between both taxa.

\section{ACKNOWLEDGEMENTS}

The prospection and excavation campaigns in the area of Araia d'Alcora have been funded by the Conselleria de Cultura i Esports of the Generalitat Valenciana from 2008 to 2011, by projects 2008/ 0433-CS, 2010/0528-CS, 2011/0230-CS, GV06/ 304 and GVPRE/2008/320. This research has also been supported by the Spanish Ministry of Economy and Competitiveness (CGL2015-68333-P). Thanks are also due to the helpful comments on the original manuscript provided by J. Guillem, R. Minwer-Barakat, L. Van den Hoek Ostende, R. Ziegler and two anonymous reviewers.

\section{REFERENCES}

Adrover, R. 1968. Los primeros micromamíferos de la cuenca valenciana, en Buñol. Acta Geológica Hispánica, 3:78-80.

Agustí, J., Anadón, P., Ginsburg, L., Mein, P., and Moissenet, E. 1988. Araya et Mira: nouveaux gisements de mammifères dans le Miocène Infèrieur-Moyen des Chaînes Ibériques orientales et méditerranéennes. Conséquences stratigraphiques et structurales. Paleontologia i Evolució, 22:83-101.

Anadón, P. 1983. Características generales de diversas cuencas lacustres terciarias con pizarras bituminosas del NE de la Península lbérica. Comunicaciones del $X$ Congreso Nacional de Sedimentología, 1:9-12. 
Barrón, E., Rivas-Carballo, R., Postigo-Mijarra, J.M., Alcalde-Olivares, C., Vieira, M., Castro, M., Pais, L., and Valle-Hernández, M. 2010. The Cenozoic vegetation of the Iberian Peninsula: a synthesis. Review of Palaeobotany and Palynology, 162:382-402. https://doi.org/10.1016/ j.revpalbo.2009.11.007

Brunet, M., Hugueney, M., and Jehenne, Y. 1981. Cournon-les Souméroux: un nouveau site à vertébrés d'Auvergne, sa place parmi les faunes de l'Oligocène Supérieur d'Europe. Geobios, 14:323-359. https://doi.org/10.1016/s0016-6995(81)80179-9

Crespo, V.D. 2017. Los Mamíferos del Mioceno Inferior de la Cuenca de Ribesalbes Alcora (Castelló, España). Unpublished Ph.D. Thesis, Universitat de València, Valencia, Spain.

Crespo, V.D., Furió, M., Ruiz-Sánchez, F.J., and Montoya, P. 2018. A new species of Plesiodimylus (Dimylidae, Eulipotyphla, Mammalia) from the early Miocene of Spain. Historical Biology, 30: 360-371. https://doi.org/10.1080/08912963.2017.1289519

Crespo, V. D., Marquina-Blasco, R., Ruiz-Sánchez, F. J. and Montoya, P. 2019b. An unusual insectivore assemblage from the early Miocene of southwestern Europe: the talpids and dimylids from the Ribesalbes-Alcora Basin (Spain). Comptes Rendus Palevol, 18:407-416. https://doi.org/10.1016/ j.crpv.2019.03.003

Crespo, V.D., Suárez-Hernando, O., Murelaga, X., Ruiz-Sánchez, F.J., and Montoya, P. 2019a. Early Miocene mammal assemblages from the Campisano ravine in the Ribesalbes-Alcora Basin (E Spain). Journal of Iberian Geology, 45:181-194. https://doi.org/10.1007/s41513018-0093-z

Doben-Florin, U. 1964. Die Spitzmäuse aus dem Altburdigalium von Wintershof-West bei Eichstätt in Bayern. Abhandlungen der Bayerischen Akademie der Wissenschaften, Mathematisch-Naturwissenschaftliche Klasse (Neue Folge), 117:1-82.

Doukas, C.S. 1986. The mammals of the lower Miocene of Aliveri (Island of Evia, Greece). Part 5. The insectivores. Proceedings Koninklijke Nederlandse Akademie van Wetenschappen, Serie $B, 89: 15-38$.

Doukas, C.S. and Van den Hoek Ostende, L.W. 2006. Insectivores (Erinaceomorpha, Soricomorpha; Mammalia) from Karydia and Komotini (Thrace, Greece; MN4/5). Beiträge zur Paläontologie, 30:109-131.

Engesser, B. 2009. The insectivores (Mammalia) from Sansan (middle Miocene, south-western France). Schweizerische Paläontologische Abhandlungen, 128:1-91.

Furió, M. and Agustí, J. 2017. Latest Miocene insectivores from Eastern Spain: evidence for enhanced latitudinal differences during the Messinian. Geobios, 50:123-140. https://doi.org/ 10.1016/j.geobios.2017.02.001

Furió, M., Casanovas-Vilar, I., and Van den Hoek Ostende, L.W. 2011. Predictable structure of Miocene insectivore (Lipotyphla) faunas in Western Europe along a latitudinal gradient. Palaeogeography, Palaeoclimatology, Palaeoecology, 304:219-229. https://doi.org/10.1016/ j.palaeo.2010.01.039

Furió, M., Prieto, J., and Van den Hoek Ostende, L.W. 2015. Three million years of "TerrorShrew" (Dinosorex, Eulipotyphla, Mammalia) in the Miocene of the Vallès-Penedès Basin (Barcelona, Spain). Comptes Rendus Palevol, 14:111-124. https://doi.org/10.1016/ j.crpv.2014.12.001

Furió, M., Ruiz-Sánchez, F.J., Crespo, V.D., Freudenthal, M., and Montoya, P. 2012. The southernmost Miocene occurrence of the last European herpetothetiid Amphiperatherium frequens (Metatheria, Mammalia). Comptes Rendus Palevol, 11:371-377. https://doi.org/ 10.1016/j.crpv.2012.01.004

Furió, M., Santos-Cubedo, A., Minwer-Barakat, R., and Agustí, J. 2007. Evolutionary history of the African soricid Myosorex (Insectivora, Mammalia) out of Africa. Journal of Vertebrate Paleontology, 27:1018-1032. https://doi.org/10.1671/02724634(2007)27[1018:ehotas]2.0.co;2

Furió, M., Van den Hoek Ostende, L., Agustí, J., and Minwer-Barakat, R. 2018. Evolución de las asociaciones de insectívoros (Eulipotyphla, Mammalia) en España y su relación con los cambios climáticos del Neógeno y el Cuaternario. Ecosistemas, 27:38-51. https://doi.org/ 10.7818/ecos. 1454

Hordijk, K., Bosma, A., de Bruijn, H., Van Dam, J., Geraedts, C., Van den Hoek Ostende, L.W., Reumer, J., and Wessels, W. 2015. Biostratigraphical and palaeoecological implications of the small mammal assemblage from the late early Miocene of Montalvos2, Teruel Basin, Spain. Palaeobiodiversity and Palaeoenvironments, 95:321-346. https://doi.org/10.1007/ s12549-015-0203-2 
Hugueney, M. and Maridet, O. 2011. Early Miocene soricids (Insectivora, Mammalia) from Limagne (Central France): new systematic comparisons, updated biostratigraphic data and evolutionary implications. Geobios, 44:225-236. https://doi.org/10.1016/ j.geobios.2010.11.006

Hugueney, M., Maridet, O., Mein, P., Mourer-Chauviré, C., and Prieto, J. 2015. Lartetium africanum (Lavocat, 1961) (Eulipotyphla, Soricidae) from Beni-Mellal (Morocco), the oldest African shrew: new descriptions, palaeoenvironment and comments on biochronological context. Palaeobiodiversity and Palaeoenvironments, 95:465-476. https://doi.org/10.1007/ s12549-015-0197-9

Hugueney, M., Mein, P., and Maridet, O. 2012. Revision and new data on the early and middle Miocene soricids (Soricomorpha, Mammalia) from central and south-eastern France. Swiss Journal of Palaeontology, 131:23-49. https://doi.org/10.1007/s13358-011-0036-1

Jovells-Vaqué, S., García-Paredes, I., Furió, M., Angelone, C., Van den Hoek Ostende, L.W., Berrocal Barberà, M., DeMiguel, D., Madurell-Malapeira, J., and Casanovas-Vilar, I. 2017. Les Cases de la Valenciana, a new early Miocene small-mammal locality from the VallèsPenedès Basin (Catalonia, Spain). Historical Biology, 30:404-421. https://doi.org/10.1080/ 08912963.2017.1317768

Klietmann, J., 2013. Systematic and Ecological Analysis of Marsupialia and Eulipotyphla from Petersbuch 28 (Germany, Lower Miocene). Unpublished Ph.D. thesis, University Vienna, Vienna, Austria.

Klietmann, J., Nagel, D., Rummel, M., and Van den Hoek Ostende, L.W. 2014. Heterosorex and Soricidae (Eulipotyphla, Mammalia) of the fissure Petersbuch 28; micro-evolution as indicator of temporal mixing? Comptes Rendus Palevol, 13:157-181. https://doi.org/10.1016/ j.crpv.2013.10.001

Klietmann, J., Van den Hoek Ostende, L.W., Nagel, D., and Rummel, M. 2015. Insectivore palaeoecology. A case study of a Miocene fissure filling in Germany. Palaeogeography, Palaeoclimatology, Palaeoecology, 418:278-289. https://doi.org/10.1016/ j.palaeo.2014.11.019

Lopatin, A.V. 2004. New early Miocene shrews (Soricidae, Mammalia) from Kazakhstan. Paleontological Journal, 38:211-219.

Minwer-Barakat, R., García-Alix, A., Martín Suárez, E., and Freudenthal, M. 2010. Soricidae (Soricomorpha, Mammalia) from the Pliocene of Tollo de Chiclana (Guadix Basin, Southern Spain). Journal of Vertebrate Paleontology, 30:535-546. https://doi.org/10.1080/ 02724631003622001

Piñero, P., Agustí, J., Furió, M., and Laplana, C. 2018. Rodents and insectivores from the late Miocene of Romerales (Fortuna Basin, Southern Spain). Historical Biology, 30:336-359. https://doi.org/10.1080/08912963.2017.1282476

Popov, V.V. 2003. Late Pliocene Soricidae (Insectivora, Mammalia) from Varshets (North Bulgaria). Acta Zoologica Cracoviensia, 46:43-72.

Postigo-Mijarra, J.M., Barrón, E., Gómez-Manzaneque, F, and Morla, C. 2009. Floristic changes in the Iberian Peninsula and Balearic Islands (south-west Europe) during the Cenozoic. Journal of Biogeography, 36:2025-2043. https://doi.org/10.1111/j.1365-2699.2009.02142.x

Reumer, J.W.F. 1984. Ruscinian and early Pleistocene Soricidae (Insectivora, Mammalia) from Tegelen (The Netherlands) and Hungary. Scripta Geologica, 73:1-173.

Reumer, J.W.F. 1995. The evolution of shrews (Mammalia, Soricidae): a key role for humidity. Geobios, 18:367-372. https://doi.org/10.1016/s0016-6995(95)80182-0

Ríos, M. 2013. Estudio Multi-isotópico de la Paleoecología y la Paleoclimatología de la Cuenca de Ribesalbes-Alcora (Castellón, España) Durante el Óptimo Climático del Mioceno. Unpublished M.D. thesis, Universitat de València, Valencia, Spain.

Robles, F., Belinchón, M., García-Flor, J., and Morales, J. 1991. El Neógeno continental de Buñol y del valle del río Cabriel. Revista Española de Paleontología, Special issue:205-215.

Rzebik-Kowalska, B. 1994. Insectivora (Mammalia) from the Miocene of Belchatów in Poland. II. Soricidae Fischer von Waldheim, 1817. Acta Zoologica Cracoviensia, 37:137-155.

Smith, R. and Van den Hoek Ostende, L.W. 2006. A new heterosoricid shrew from the lowermost Oligocene of Europe. Acta Palaeontologica Polonica, 51:381-384.

Storch, G. and Qiu, S. 1991. Insectivores (Mammalia: Erinaceidae, Soricidae, Talpidae) from the Lufeng hominoid locality, late Miocene of China. Geobios, 24:601-621. https://doi.org/ 10.1016/0016-6995(91)80025-u 
Storch, G. and Qiu, Z. 2004. First complete heterosoricine shrew: a new genus and species from the Miocene of China. Acta Palaeontologica Polonica, 49:357-363.

Van Dam, J.A., Furio, M., and Van Balen, R.T. 2014. Re-interpreting the biochronology of the La Celia and Los Gargantones mammal sites (late Miocene, Murcia, Spain). Geobios, 47:155164. https://doi.org/10.1016/j.geobios.2014.03.002

Van den Hoek Ostende, L.W. 1995. Insectivore faunas from the lower Miocene of Anatolia. Part 2: Dinosorex (Heterosoricidae). Proceedings of the Koninklijke Nederlandse Akademie van Wetenschappen, 98:1-18.

Van den Hoek Ostende, L.W. 2001a. Insectivore faunas from the lower Miocene of Anatolia. Part 8: stratigraphy, palaeoecology, palaeobio-geography. Scripta Geologica, 122:101-122.

Van den Hoek Ostende, L.W. 2001b. Insectivore faunas from the lower Miocene of Anatolia. Part 6: Crocidosoricinae (Soricidae). Scripta Geologica, 122:47-81.

Van den Hoek Ostende, L.W. 2003. Insectivores (Erinaceomorpha, Soricomorpha, Mammalia) from the Ramblian of the Daroca-Calamocha area. Coloquios de Paleontología, Special Issue 1:281-310.

Van den Hoek Ostende, L.W., Álvarez-Sierra, M.A., García-Paredes, I., Montoya, P., RuizSánchez, F.J., and Peláez-Campomanes, P. 2017. Alto de Ballester, biogeographical consequences of atypical MN 3 micromammal assemblages from eastern Spain.

Palaeontographica Abteilung, Serie A, 308:127-175. https://doi.org/10.1127/pala/308/2017/ 127

Van den Hoek Ostende, L.W. and Furió, M. 2005. Spain, In van den Hoek Ostende, L.W., Doukas, C.S., and Reumer, J.W.F. (eds.), The fossil record of the Eurasian Neogene insectivores (Erinaceomorpha, Soricomorpha, Mammalia), Part I. Scripta Geologica, Special issue, 5:149-284.

Van den Hoek Ostende, L.W., Furió, M., and Garcia-Paredes, I. 2009. New data on Paenelimnoecus from the middle Miocene of Spain support the shrew subfamily Allosoricinae. Acta Palaeontologica Polonica, 54:159-164. https://doi.org/10.4202/ app.2009.0117

Van den Hoek Ostende, L.W., Furió, M., Madern, A., and Prieto, J. 2016. Enters the shrew, some considerations on the Miocene palaeobiogeography of Iberian insectivores. Comptes Rendus Palevol, 15:813-823. https://doi.org/10.1016/j.crpv.2016.03.006

Van der Meulen, A.J., García-Paredes, I., Álvarez-Sierra, M.Á., Van den Hoek Ostende, L.W., Kordijk, K., Oliver, A., and Peláez-Campomanes, P. 2012. Updated Aragonian biostratigraphy: small mammal distribution and its implications for the Miocene European chronology. Geologica Acta, 10:159-179.

Ziegler, R. 1989. Heterosoricidae und Soricidae (Insectivora, Mammalia) aus dem Oberoligozä $\mathrm{n}$ und Untermiozän Süddeutschlands. Stuttgarter Beiträge zur Naturkunde, Serie B, 154:1-73.

Ziegler, R. 1999. Order Insectivora, p. 53-74. In Rössner, G.E., Heissig, K. (eds.), The Miocene Land Mammals of Europe. Verlag Dr. Friedrich Pfeil, München.

Ziegler, R. 2006. Miocene Insectivores from Austria and Germany - an overview. Beiträge zur Paläontologie, 30:481-494.

Ziegler, R. and Fahlbusch, V. 1986. Kleinsäuger-Faunen aus der basalen Oberen SüßwasserMolasse Niederbayerns. Abhandlungen der Bayerischen Staatssammlung für Paläontologie und Historische Geologie. Zitteliana, 14:3-80.

Ziegler, R. and Mörs, T. 2000. Marsupialia, Lipotyphla und Chiroptera (Mammalia) aus dem Miozän des Braunkohlentagebaus Hambach (Niederrheinische Bucht, NW-Deutschland). Palaeontographica Abteilung, Serie A, 257:1-26. 